\title{
Erasmus' Translations of Plutarch's Moralia and the Ascensian editio princeps of ca. 1513
}

\author{
JORGE LEDO
}

The role of Erasmus as a disseminator of Plutarch's Moralia has been frequently studied. As far as the editorial history of the Moralia is concerned, Erasmus, who had served as an assistant to Demetrius Ducas on the Aldine edition of 1509, began to translate the opuscula in Cambridge. Until now, these translations were thought to have been published for the first time in a single volume by Johannes Froben in Basel (August 1514). This article proves that not only did Erasmus send his translations to Badius, but that the latter printed them before Froben, in a hitherto unknown editio princeps. ${ }^{*}$

\section{Status quaestionis ${ }^{* *}$}

As with most of his fellow humanists from outside Italy up to the end of the first decade of the sixteenth century, Erasmus' knowledge of Plutarch must have been limited to Latin translations of some Parallel Lives, although he was aware of the existence of the Moralia, which he even quoted, albeit rarely, in the Adagiorum collectanea. ${ }^{1}$ It was in

* I would like to express my gratitude to Erika Rummel for her kind answer when I first showed her the Ascensian print of Erasmus' Opuscula Plutarchi, to the Erasmus of Rotterdam Society for inviting me to make known the finding in their panel at the Renaissance Society of America's Annual Conference (Toronto, March 2019), and to such kind, generous, and patient readers of the first versions of this manuscript as Andrew Ascherl, Eric MacPhail, and Jon Nelson. To all of them, my warmest thanks.

${ }^{* *}$ Recent scholarship has repeatedly appraised the role played by Erasmus as disseminator of Plutarch's Moralia. Therefore, to introduce the problem of the first edition of Erasmus' Latin translation of a selection of Plutarch's Moralia, I will provide only the most general data found in contemporary bibliography. Abbreviations used: Allen = P.S. Allen, H.M. Allen, H.W. Garrod (ed.), Opus epistolarum D. Erasmi Roterodami (Oxford, 1906-1958); ASD = Opera omnia Desiderii Erasmi Roterodami (Amsterdam, 1969- ); $\mathrm{CWE}=$ Collected Works of Erasmus (Toronto, 1974- ).

${ }^{1}$ The Quattrocento translations into Latin of the Moralia have been studied by, among others, R. Sabbadini, La scuola e gli studi di Guarino Veronese (Catania, 1896), 135-138; R. Aulotte, Amyot et Plutarque. La tradition des Moralia au XVIe siècle (Genève, 1965), 22-26; F. Tateo, "Sulle traduzioni umanistiche di Plutarco. Il De virtute morali di Andrea Matteo Acquaviva", in M. Ciliberto, C. Vasoli (ed.), Filosofia e cultura. Per Eugenio Garin (Roma, 1991), 198-211; C. Bevegni, "Teodoro Gaza traduttore del Maxime cum principibus philosopho esse disserendum di Plutarco. Primi appunti per un'edizione critica con particolare riguardo alla lettera dedicatoria ad Andrea Bussi", in S. Feraboli 


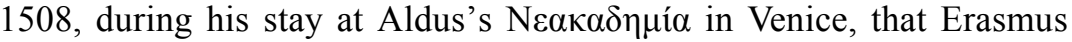
had access for the first time to a Greek manuscript containing all the Moralia. ${ }^{2}$ Erasmus' words in one of the best known adagia of the Chiliades, "Festina lente", written in 1526, are quite eloquent about the impact that the Moralia and other Greek manuscripts had on the Adagia and on his education:

When I, a Dutchman, was in Italy, preparing to publish my Book of Proverbs, all the learned men there had offered me unsought authors not yet published in print who they thought might be of use to me, and Aldus had nothing in his treasure-house that he did not share with me. Johannes Lascaris did the same; so did Battista Egnazio, Marco Musuro, Frate Urbano. I felt the benefit of kindness from some people I knew neither by sight nor name [...]. Just consider what advantages I should have lost, had not scholars supplied me with texts in manuscript. Among them were Plato's works in Greek, Plutarch's Lives, and also his Moralia, which began to be printed when my work was nearly finished; the Doctors at Dinner of Athenaeus, Aphthonius, Hermogenes with notes, Aristotle's Rhetoric with the Scholia of Gregory of Nazianzus, the whole of Aristides with Scholia, brief commentaries on Hesiod and Theocritus, Eustathius on the whole of Homer, Pausanias, Pindar with accurate commentary, a collection of proverbs under Plutarch's name and

(ed.), Mosaico. Studi in onore di Umberto Albini (Genova, 1993), 33-42; Id., "Appunti sulle traduzioni latine dei Moralia di Plutarco nel Quattrocento", Studi umanistici piceni 14 (1994), 71-84; F. Stok, "Le traduzioni latine dei Moralia di Plutarco", Fontes 1 (1998), 117-136; and F. Becchi, "Le traduzioni latine dei Moralia di Plutarco tra XIII e XVI secolo", in P. Volpe Cacciatore (ed.), Plutarco nelle traduzioni latine di età umanistica (Napoli, 2009), 9-52. According to Bevegni's census, in fifteenth-century Italy alone 32 titles of the Moralia were translated into Latin, in 60 renderings authored by 23 different translators. In France, in 1505, Guillaume Budé published his translations of four Moralia; see G. Sandy, "Guillaume Budé: Philologist and Polymath. A Preliminary Study", in Id. (ed.), The Classical Heritage in France (Leiden - Boston, MA - Köln, 2002), 83-87. Erasmus had a copy of this volume in his private library.

2 Erasmus' stay at Aldus's house in Venice has been studied from many different points of view. There are documented introductions by D.J. Geanakoplos, "Erasmus and the Aldine Academy of Venice. A Neglected Chapter in the Transmission of GraecoByzantine Learning to the West", Greek, Roman and Byzantine Studies 3 (1960), 107-134; reissued in Id., Greek Scholars in Venice (Cambridge, MA, 1962), 256-278, and J.-C. Margolin, "Érasme et Venise", in G. Benzoni (ed.), L'eredità greca e l'ellenismo veneziano (Firenze, 2002), 189-213. A good summary of Erasmus' tensions with Aldus' press and its heirs over the years can be found in L. Perilli, "A Risky Enterprise. The Aldine Edition of Galen, the Failures of the Editors, and the Shadow of Erasmus of Rotterdam”, Early Science and Medicine 17.4 (2012), 446-466. 
another ascribed to Apostolius, to which I was given access by Girolamo Aleandro. ${ }^{3}$ (CWE 33, 14)

Erasmus and Girolamo Aleandro served, indeed, as proof-readers of the first printing of the Greek text of Plutarch's Moralia, edited by Demetrius Ducas, one of the Byzantine scholars at Aldus's house. ${ }^{4}$ This edition was printed in March 1509, and one copy traveled with Erasmus to England and remained in his personal library for good. ${ }^{5}$ Once he had

3 Adag. 1001, "Festina lente": "Cum apud Italos aederem proverbiorum opus homo Batavus, quotquot illic aderant eruditi, ultro suppeditabant autores nondum per typographos evulgatos, quos mihi suspicabantur usui futuros. Aldus nihil habebat in thesauro suo quod non communicaret, idem fecit Ioannis Lascaris, Baptista Egnatius, Marcus Musurus, frater Urbanus. Quorundam officium sensi, quos nec de facie, nec de nomine noveram [...] Hic mihi cogita, quanta pars utilitatis abfutura fuerit, nisi docti libros manu descriptos suppeditassent. In his erant Opera Platonis Graeca, Plutarchi Vitae, eiusdem Moralia, quae sub finem operis mei coepta sunt excudi, Athenaei Dipnosophistae, Aphthonius, Hermogenes cum commentariis, Aristotelis Rhetorica cum scholiis Gregorii Nazianzeni, Aristides totus cum scholiis, commentarioli in Hesiodum ac Theocritum, Eustathius in totum Homerum, Pausanias, Pindarus cum accuratis commentariis, proverbiorum collectio titulo Plutarchi, rursus alia titulo Apostolii, cuius libri nobis copiam fecit Hieronymus Aleander." (ASD 2.3, 22-24)

${ }^{4}$ Geanakoplos 1962 (as in n. 2), 223-224, 229, 264, 275, offers insights and relevant bibliography on how Ducas worked on his text; M. Sicherl, "Die Aldina der Rhetores Graeci (1508-1509) und ihre handschriftlichen Vorlagen", Illinois Classical Studies 17.1 (1992), 109-134, at 126, traces parallels with Ducas' edition of the Rhetores Graeci. M. Dazzi, Aldo Manuzio e il dialogo veneziano di Erasmo (Venezia, 1969) and N.G. Wilson, Da Bisanzio all'Italia. Gli studi greci nell'umanesimo italiano (Alessandria, 2003), 192, do not provide further information in this regard. The prefatory materials of the Aldine Moralia (1509) have been recently edited and translated by L. Ferreri (ed.), L'Italia degli umanisti. I. Marco Musuro (Turnhout, 2014), 356-363. N.G. Wilson (ed., tr.), Aldus Manutius, The Greek Classics (Cambridge, MA - London, 2016), 200207 , offers the edition and translation of Aldus' preface. Short introductions to the role played by Greek émigrés in Renaissance culture and print and to relevant bibliography can be found in M.I. Manoussakas, K.S. Staikos (ed.), L'activité editoriale des Grecs pendant la Renaissance. De l'Italie à Genève, $X V^{e}-X V I^{e}$ siècle (Athènes, 1988); M.I. Manoussakas, Gli umanisti greci collaboratori di Aldo a Venezia (1494-1515) e l'ellenista bolognese Paolo Bombace (Bologna, 1991); E. Layton, The Sixteenth Century Greek Book in Italy. Printers and Publishers for the Greek World (Venice, 1994); and J. Monfasani, "Greek Renaissance Migrations", Italian History and Culture 8 (2002), 1-14.

${ }^{5}$ No. 208 in the Versandliste of 1536. F. Husner, "Die Bibliothek des Erasmus", in Historische und Antiquarische Gesellschaft zu Basel (ed.), Gedenkschrift zum 400. Todestage des Erasmus von Rotterdam (Basel, 1936), 240, and E. van Gulik, Erasmus and His Books (Toronto - Buffalo, NY - London, 2018), 170, 339. Van Gulik mentions that Erasmus' personal copy of the Moralia (1509), containing his own handwritten marginal notes, was held in the Old University Library of Franeker. Thanks to the finding in 2007 by G.C. Huisman of the printed catalogue of Franeker of 1601 (Paris, Bibliothèque de l'Arsenal, 8-H-26084[3]; http://www.mpaginae.nl/Frnkroudstecat/Franeker1601.htm, B4), 
arrived in England, at least four reasons would have moved Erasmus to translate a selection of the Moralia into Latin: their combination of brevity, classical learning, and moral instruction; their more direct and less problematic approach to morals than that of Lucian's opuscules; the scarcity of printed translations into Latin of the Moralia; and Erasmus' interest in advancing his own study of Greek. Thus, he began the task shortly after he settled in Cambridge in $1511 .^{6}$ During his career, Erasmus would translate eleven opuscules contained in the Moralia subsequently published as Opuscula Plutarchi -, and compose the Parabolae sive Similia (1514) and the Apophthegmata (1531), both relying heavily on Plutarch.

Returning to the Moralia: Erasmus published one of his first translations, Advice about keeping well (De tuenda bona valetudine praecepta), at Richard Pynson's press in London on 28 July $1513 .{ }^{7}$ Thereafter, he dedicated How to tell a flatterer from a friend (Quo pacto possis adulatorem ab amico dignoscere) to Henry VIII, and How to profit by one's enemies (Quo pacto quis efficiat ut ex inimicis capiat utilitatem) to Thomas Wolsey, Bishop of Lincoln. ${ }^{8}$ It seems clear that Erasmus had

the hypothesis that Erasmus' copy of Plutarch's Moralia should have arrived in Franeker after 1626 must be discarded - this could be inferred until now from M. Engels, "Erasmiana in the Old University Library of Franeker", Erasmus in English 12 (1983), 20a-b. In his scholarly edition of the catalogue of 1601 and in further research, J. van Sluis has shown that four Aldine editions of classical authors which pertained to Erasmus arrived in Franeker when the library acquired the collection of Petrejus Tiara ( $† 9$ February 1586): J. van Sluis, De academiebibliotheek te Franeker anno 1601. De oudste catalogus ingeleid en opnieuw uitgegeven (Franeker, 2011), 193-198; Id., "Erasmus, Tiara en de eerste collectie van de Franeker academiebibliotheek", It Beaken 78 (2016), 141-142. These editions were Dioscorides' De materia medica, with Nicander's Theriaca and Alexipharmaca (1499); Plutarch's Moralia (1509) and Parallel Lives (1519); and Galen's Works (1525).

${ }^{6}$ Erasmus arrived in England in 1509 and lived in London for a year and a half. His appointment as a reader of Divinity and Greek at Cambridge was the main reason for leaving the city. He had his residence in Cambridge from August 1511 to January 1514. On his stay there, see D.F.S. Thomson, H.C. Porter (ed.), Erasmus and Cambridge. The Cambridge Letters of Erasmus (Toronto, 1963); and R.J. Schoeck, Erasmus of Europe. The Prince of Humanists. 1501-1536 (Edinburgh, 1993), 109-125.

7 For this and other works of Erasmus printed by Pynson, see A. Vanautgaerden, "Érasme chez Richard Pynson (1513), imprimeur du roi à Londres", Moreana 46.176 (2009), 199-201; and Id., Érasme typographe. Humanisme et imprimerie au début du XVIe siècle (Genève, 2012), 219-228.

8 Respectively, Allen 272 (CWE 2, 250-252) and Allen 297 (CWE 2, 303-305). Despite the outward appearance, in the catalogue of his works sent to Johann von Botzheim (30 January 1523) Erasmus is not following the chronological order he adopted for the translations of the Moralia (see J. Chomarat, Grammaire et rhétorique chez Érasme, vol. 1 (Paris, 1981), 472; cf. GG 13 in the online catalogue Griechischer Geist 
decided to proceed with his translations of Plutarch as he had done with Lucian in 1506, addressing each translation to a potential patron in order to increase the returns; but something happened that dissuaded him from following this course. Thus, the rest of the Moralia translated by him lack any dedicatory letters, with the exception of those he finished a decade later. ${ }^{9}$ We can only guess at the reason behind this, but it is probably related to Erasmus' move to Basel in 1514, as it would have seemed to him unnecessary and time-consuming to look for more patrons in England when he was headed to the Continent, and the absence of prefatory letters and dedications in print to his existing English patrons between 1516 and 1520 is a rather telling hiatus. ${ }^{10}$

aus Basler Pressen, http://www.ub.unibas.ch/cmsdata/spezialkataloge/gg/), but rather Froben's table of contents of 1514: "From Plutarch I translated an essay called Quomodo sit dignoscendus adulator ab amico, which I dedicated to the English king Henry, eighth of that name. Besides that, one Quo pacto fieri possit ut utilitatem capias ex inimico; this I dedicated to the man who is now cardinal-archbishop of York, who at that time was Lord High Almoner but was already destined for great things, so much so that before I had an opportunity to present it to him, I had to change my preface three times, and even so, before it could be printed, he had already reached the dignity of a cardinal [Erasmus refers to the summer of 1514]. Before those, I had translated Plutarch's De tuenda valetudine, Quod in principe requiratur eruditio, Quod cum principibus maxime versari debeat philosophus, Utrum graviores sint animi morbi an corporis, Num recte dictum sit, $\Lambda \alpha ́ \theta \varepsilon$ $\beta 1 \omega \sigma \alpha \varsigma$, De cupiditate divitiarum. These exercises I enjoyed all the more because they contributed substantially to the building of character no less than to the learning of Greek; for I have read nothing outside Scripture with such a high moral tone", Allen 1, 16-30; CWE 9 (1341a), 302-303.

${ }^{9}$ E. Rummel, Erasmus as a Translator of the Classics (Toronto - Buffalo, NY London, 1985), 74: "The three translations were published by Froben in 1525 and 1526 respectively." The dedicatory letters are Allen 1572 (That anger must be controlled [De cohibenda iracundia] and On meddlesomeness [De curiositate], to Alexius Thurzo), and Allen 1663 (On false shame [De vitiosa verecundia], to Francis Dilft).

${ }^{10}$ Rummel 1985 (as in n. 9), 74, stresses the fact that his dedications to his English patrons had been poorly rewarded, according to Erasmus' standards, during his stay in England. However, it should be noted that he was active behind the scenes with his English patrons during this period, as C.H. Clough explained in "Erasmus and the Pursuit of English Royal Patronage in 1517 and 1518", Erasmus of Rotterdam Society Yearbook 1.1 (1981), 126-140, and that, after the hiatus, Erasmus did not cease dedicating works to his English patrons, as demonstrated by the list provided by C.R. Thompson, "Erasmus and Tudor England", in C. Reedijk (ed.), Actes du Congrès Érasme organisé par la municipalité de Rotterdam sous les auspices de l'Académie Royale Néerlandaise des Sciences et des Sciences Humaines. Rotterdam 27-29 octobre 1969 (Amsterdam - London, 1971), 3435 , n. 27. There are valuable approaches to Erasmus and patronage in England in Garrod's and McConica's essays mentioned in Thompson's footnote, to which should be added Clough's cited essay and J.B. Trapp's "Twelfth-Annual Birthday Lecture. Erasmus and His English Friends”, Erasmus of Rotterdam Society Yearbook 12.1 (1992), 18-44. 
Besides his project of publishing a new, enlarged edition of the Adagia, Erasmus was interested in gathering his translations of the Moralia into a single volume, as he had done with Lucian; he would do this without delay in $1514 .{ }^{11}$ To Pieter Gillis, an editor at Martens' press and Erasmus' editorial contact in Antwerp as well as one of his closest friends at the time, Erasmus wrote the following words in autumn 1512:

Please see that this is delivered to Josse Bade as soon as possible. I have got my work on proverbs ready [i.e., the revised version of the Adagia], expanding it so much that I have quite changed its character - and improved it a great deal, unless I am mistaken, though it was not so bad before; so he has no need to fear editions by others. There had been an understanding with Franz [Birckmann], the bookseller, that I was to give him the manuscript; but he went off without coming to greet me. I gladly accept the price proposed by him in his letter; money, for what it is worth, does not greatly move me. He should take all measures to ensure that the work emerges from his press in a style that will make it difficult for anyone else to compete [...]. I have not yet seen any sign of the publication of Lucian's Dialogues which I sent him, while I do notice that some of them have been printed at Louvain; I am anxious for information about this. I have translated several works by Plutarch, which I shall revise and send in addition. ${ }^{12}$ (CWE 2, 234-235)

Three important statements made in this passage determine the editorial history of Erasmus' Opuscula Plutarchi. First, Erasmus declares that he had an agreement with Franz Birckmann ${ }^{13}$ to collect the manuscript of

${ }^{11}$ Both printed by Badius before Froben began publishing them. C.R. Thompson (ed.), The Complete Works of St. Thomas More, vol. 3 (New Haven, CT - London, 1974), 1viilviii, offers descriptions of Erasmus' and More's Lucian printed in 1514 by Badius.

12 "Dabis operam ut haec quam primum ad Iodoci Badii manus perferantur. Paravi Proverbiorum opus et ita locupletavi ut prorsus aliud reddiderim: at multo, ni fallor, melius cum esset non admodum malum. Quare nihil est quod aliorum timeat aeditiones. Convenerat cum Francisco bibliopola ut illi exemplar committerem, verum insalutato me discessit. Precium quod in suis literis praescripsit, lubens accipio; nec enim magnopere commoveor lucello. Ipse paret omnia, ut opus sic exeat ex ipsius officina ut non facile sit cuipiam aemulari. [...] Dialogos Luciani, quos ad eum misi, nondum prodire video. Video quosdam ex illis excusos Lovanii; qua de re cupio certior fieri. Verti complusculos Plutarchi libros, quos emendatos addemus." (Allen 264, 5-13 and 22-25)

${ }^{13}$ Besides the entry by Bietenholz and Guenther in Contemporaries of Erasmus, further research on the role of Birckmann as a literary agent for Erasmus and as a scout for Badius' and Froben's presses can be found in D. Shaw, "A Study of the Collaboration between Erasmus of Rotterdam and His Printer Johann Froben at Basel during the Years 
his revised version of the Adagia and deliver it to Badius Ascensius in Paris, who was asking for it (Allen 263, 16-49; CWE 2, 232-234), but Birckmann did not come to see him. Second, he complains about the lack of news on his translations of Lucian's Dialogues sent to Badius to be printed, a lack aggravated by the fact that they had already been published by Martens in Louvain. ${ }^{14}$ Third and most important, Erasmus promises to send, included with his next epistle to Badius, his translation of some of the Moralia for publication: "which I shall revise and send in addition" ("Verti complusculos Plutarchi libros, quos emendatos addemus").

There is no further mention of the translations of the Moralia in Erasmus' letters until 1 January 1513. This is the date of the dedicatory letter to John Yonge appended to his translation of Advice about keeping well (De tuenda bona valetudine praecepta; Allen 268; CWE 2, 239241). As I have already mentioned, the letter and the opuscule were printed by Richard Pynson's press in London (in July 1513) and soon thereafter by at least one press on the Continent. ${ }^{15}$ That same July Erasmus dispatched a brief letter to Thomas More (Allen 271; CWE 2, 249-250) to inform him about the progress he was making in translating yet another opuscule by Plutarch: How to tell a flatterer from a friend (Quo pacto possis adulatorem ab amico dignoscere or De discrimine adulatoris et amici), which he dedicated to Henry VIII, remarking "I shall finish it, God willing, within a week" ("Absolvam faventibus superis intra dies octo"; Allen, 271, 8-9; CWE 2, 249).

Between July and December 1513, Erasmus took action with regard to the publication of his Opuscula Plutarchi. In a letter to Andrea

1514 to 1527", Erasmus of Rotterdam Society Yearbook 6 (1986), 49-51, 75-76; K. Crousaz, Érasme et le pouvoir de l'imprimerie (Lausanne, 2005), 24-25, 50-51, 55-57, 113-114; Vanautgaerden 2012 (as in n. 7), 207, 229-237, 240, 245, 250 n. 1, 258, 460; V. Sebastiani, Johann Froben, Printer of Basel. A Biographical Profile and Catalogue of His Editions (Leiden - Boston, MA, 2018), 44 n. 18, and 70; and Van Gulik 2018 (as in n. 5), 26-27, 335, 434.

${ }^{14}$ Badius finally printed the Luciani Dialogi in June of 1514. See above, n. 11.

15 It was also printed by Thierry Martens in November 1513, in a volume which included Erasmus' translation of Lucian's De luctu without any mention on the title page of its incorporation in the volume; see Vanautgaerden 2012 (as in n. 7), 427, 503. Erasmus kept a copy either from Pynson's or Martens' press, as the Catalogus librorum Erasmi attests; see Van Gulik 2018 (as in n. 5), 455, 469. 
Ammonio (Allen 283; CWE 2, 267-275) ${ }^{16}$ he explains the progress he has made (with the assistance of Franz Birckmann) as follows:

I had entrusted an emended and enlarged text [of the Adagia] to Franz, who is accustomed to import almost every book into this country, intending him to hand it over to Bade or, if he advised it, to another publisher. That worthy immediately carried it off to Basel and put it in the care of the man who had already printed it, so that he will publish this edition only when he has sold all the copies of his own, that is, ten years from now. Also there are several books translated from Plutarch and Lucian which I had entrusted to him to give to Bade, to be added to the previous books he has in his possession; and I suspect he has given these also to the other man, and now he is asking me to send more of them. There is German honesty for you! But there is a way in which I can get my own back: a copy of the Adagia, and, in fact, a rather more comprehensive one than the copy he took, has been kept. He will find one Cretan can be a match for another. ${ }^{17}$ (CWE 2, 273)

Until now, textual evidence has allowed us to understand this passage only in the following way: even if Erasmus trusted Birckmann to hand over the manuscripts of the Moralia and the Adagia to Badius Ascensius, the latter decided motu proprio to give them to Froben instead, no doubt for economic reasons and probably with Erasmus' tacit permis-

${ }^{16}$ Ammonio died on 16 August 1517. For Erasmus' friendship with him and Ammonio's activities while Erasmus was in England, see C. Pizzi, Un amico di Erasmo. L'umanista Andrea Ammonio (Firenze, 1956); J.K. Sowards, "The Two Lost Years of Erasmus. Summary, Review, and Speculation", Studies in the Renaissance 9 (1962), 161186; J.D. Tracy, Erasmus. The Growth of a Mind (Genève, 1972), 112, 127-129, 135-137, 164; C.H. Miller, "The Epigrams of Erasmus and More. A Literary Diptych", Erasmus of Rotterdam Society Yearbook 1.1 (1981), 11-13; Schoeck 1993 (as in n. 6), ad indicem; H. Yoran, Between Utopia and Dystopia. Erasmus, Thomas More, and the Humanist Republic of Letters (Plymouth, 2010), 39-44; M. Rospocher, "Genesi di un discorso politico. Un interlocutore sconosciuto di Erasmo", in E.A. Baldini, M. Firpo (ed.), Religione e politica in Erasmo da Rotterdam (Roma, 2012), 88-89, 97-98; D.R. Carlson, "Erasmus and the War-Poets in 1513", Erasmus Studies 34.1 (2014), 5-49, at 14-19; T.L. Ter Meer, "The Miraculous Versatility of Apophthegms", Erasmus Studies 34.2 (2014), 81.

17 "Commiseram exemplar emendatum ac locupletatum Francisco, qui libros ferme omnes solitus est huc importare, ut vel Badio vel ex illius sententia committeret alii. Is bonus vir recta Basileam deportavit, ei in manus dedit qui iam excuderat, ut haec tum demum aedat cum sua divendiderit, hoc est post decennium. Complures item libellos ex Plutarcho ac Luciano versos commiseram Badio tradendos, ut superioribus quos habet adiungeret; et hos illi, uti suspicor, tradidit, utque plures mittam rogat. En Sicambricam fidem; sed est quo me ulciscar. Servatum est Adagiorum exemplar, et quidem aliquanto copiosius eo quod ille abstulit. Cretissabimus cum Cretensi." (Allen 283, 154-164) 
sion. Valentina Sebastiani ${ }^{18}$ has explained accurately that the tensions between Badius' and Froben's presses contrasted with the friendship of their respective proof-readers, Michael Hummelberger (or Hummelberg) and Beatus Rhenanus, ${ }^{19}$ who met during their student years in Paris; thus making it likely that everyone was aware of the situation that would finally result in the edition of the Adagia printed by Froben. ${ }^{20}$

Nonetheless, if we pay attention to a couple of details in the passage drawn from the letter to Ammonio, we can derive an alternate reading which shows that the situation was somewhat more complicated. Erasmus declares to Ammonio that he had trusted Birckmann to give Badius "several books translated from Plutarch and Lucian [...] to be added to the previous books he has in his possession". In other words, if Erasmus began to translate Plutarch in 1512 and first mentions the Plutarchi opuscula in the letters he wrote in autumn 1512 (to assert that Birckmann had not handed them over to Badius), this would necessarily mean that at some point between autumn 1512 and December 1513,

${ }^{18}$ Sebastiani 2018 (as in n. 13), 40, 42 and n. 9.

19 Hummelberger kept up an assiduous correspondence with some of the greatest German scholars and literary figures of his time. He corresponded frequently not only with Beatus Rhenanus but also with Konrad Peutinger, Bruno Amerbach, Johannes Reuchlin, Mutianus Rufus, and Heinrich Bebel, to mention just a few. He assisted Badius until he left Paris to study in Rome (1514-1517), where his patron was John Goritz of Luxemburg. Once back in Ravensburg as chaplain of St Michael's church, he met Erasmus in person in Constance in September 1522, became close friends with Johann von Botzheim and grew to be an admirer of Erasmus' work. See CWE 10, 282 n. 1, and CWE 12, 448 n. 10.

${ }^{20}$ If this hypothesis is correct, it would nonetheless be necessary to infer that Hummelberger kept silent about (or was unaware of) the (unauthorised?) printing of the Opuscula Plutarchi in Badius' press. This fact alone would explain why Beatus Rhenanus, in a letter addressed to Hummelberger on 2 September 1514, presented Erasmus' translations of the Moralia as an editorial premiere: "Erasmus of Rotterdam, a man of very high erudition, recently came to Basel loaded with good books, among which: the complete works of Saint Jerome, amended; the complete works of Seneca, amended; very abundant annotations on the New Testament; the Parallels; many works of Plutarch in translation. [...] Likewise the Adages, corrected and considerably increased. Some opuscules by Plutarch, elegantly printed, will invade the shop these days" (my translation of "Erasmus Roterodamus, summae eruditionis vir, nuperrime Basileam venit onustus bonis libris in quibus sunt haec: omnia opera divi Hieronymi emendata; omnia opera Senecae emendata; annotationes in Novum Testamentum copiosissimae; liber similium; Plutarchi multa versa; [...] item Adagia castigata et auctissima. Plutarchi opuscula aliquot hiis diebus officinam aggredientur eleganter excusa", in J. Hirstein (ed.), Beatus Rhenanus, Epistulae Beati Rhenani. La correspondance latine et grecque de Beatus Rhenanus de Sélestat, vol. 1 (Turnhout, 2013), 482-486, spelling adapted). However, Beatus' allusion to this volume as "elegantly printed" ("eleganter excusa"), clearly an exaggeration, suggests that he suspected that Badius had a copy of the Opuscula. 
Birckmann did in fact give some of Erasmus' translations of Plutarch to Badius, and - quite probably - to Johannes Froben.

However, it is widely accepted among Erasmus scholars that the copies of the translations of the Moralia were given only to Froben, who published them in Basel in August 1514, thus marking the beginning of one of the most famous printer-author collaborations of the Renaissance. ${ }^{21}$ Valentina Sebastiani gives a description of the title page of what has been considered (until now) the editio princeps:

Opuscula Plutarchi nuper traducta.|| Erasmo Roterodamo Interprete.|| Quo pacto q[ui]s dignoscere possit adu|llatorem ab amico.|| Quo pacto quis efficere possit ut ca-||piat utilitatem ab inimico.|| De tuenda bona ualetudine praecepta.|| In principe requiri doctrinam.|| Cum principibus maxime philoso-\|phum debere disputare.|| Vtrum grauiores sint animi morbi,|| quam corporis.|| Num recte dictu[m] sit, lathe biōsas, id est,\| Sic uiue ut nemo te sentiat uixisse.|| De cupiditate divitiarum.|| Gerardou tou Listriou|| Tauta d'arēiphilōn Germanōn kosmos Erasmos|| Oios leimōnōn drepsato ek danaōn.||. ${ }^{22}$

\section{A new editio princeps of Erasmus' translation of the Moralia}

What I will argue in the remaining pages is that Badius Ascensius did in fact print an edition of the Plutarchi opuscula translated by Erasmus, and that this printing was, for reasons I shall mention, the editio princeps of the collection, rather than Froben's. For the description, I have employed three volumes extant in the Universiteitsbibliotheek of Ghent: two copies of the Ascensian edition, which I will suggest were printed in 1513 or at the beginning of 1514 (BIB.G.009091/-1, PLATE 1, and BIB.G.009211, Plate 2), and the Frobenian edition of the Moralia from August 1514 (BIB.ACC.021196/-1, Plate 3). As far as I know, the Ascensian printing is neither registered in any catalogue of Erasmus'

${ }^{21}$ S.J. Ryle, "Language and Silence in Erasmus", Res Publica Litterarum. Studies in the Classical Tradition 14 (1991), 205-206; Vanautgaerden 2012 (as in n. 7), 282, 503.

22 Sebastiani 2018 (as in n. 13), 197-199. The colophon (sig. d5v) reads: "Basileae in aedibus Ioannis Frobenii Hammel||burgensis, mense Augusto, Anno domini mil-||lesimo quingentesimo decimoquarto." 
works, nor was it used in A.J. Koster's critical edition of the Opuscula in ASD 4.2. ${ }^{23}$ The Parisian imprints share identical title pages: ${ }^{24}$

Opuscula Plutarchi nup[er] tradu-||cta. Erasmo Roterodamo interprete.|| De tuenda bona valitudine praecepta.|| In principe requiri doctrinam.|| Cum principibus maxime philosophum debere disputare.\| Vtrum grauiores sint animi morbi q[uam] corporis.|| Num recte dictum sit

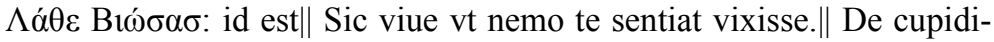
tate diuitiarum.|| [image]|| Vaenundantur vbi complura alia, \& Plutarchi \& Erasmi || syntagmata, in aedibus Ascensianis.

None of them, however, offer any further information concerning when or under which circumstances Badius received the translations; nor do they include a colophon with a printing date. Luckily, a comparison of the editio Ascensiana and the editio Frobeniana allows us to draw the conclusion that the editio Ascensiana [henceforth OPAsc] was most likely printed earlier than the editio Frobeniana of 1514 [henceforth OPFrob].

For the sake of both brevity and clarity, I will mention only the main differences and similarities between the two editions, and will close with a hypothetical reconstruction of the editorial history of both editions.

The first difference between them is the census of Moralia contained in each volume. Only OPFrob includes How to tell a flatterer from a friend (Quo pacto possis adulatorem ab amico dignoscere), accompanied by the dedicatory epistle to Henry VIII, and How to profit by one's enemies (Quo pacto quis efficiat ut ex inimicis capiat utilitatem) with the letter to Thomas Wolsey, Bishop of Lincoln. Both the Ascensiana and the Frobeniana include the Advice about keeping well (De tuenda bona valetudine praecepta) without the dedicatory epistle to John Yonge. Therefore, the Ascensiana gathers nums. 3-8 from ASD 4.2. This constitutes a difference of 47 printed pages in OPAsc - involving some artifice, as we will see - compared to the 101 pages of OPFrob.

23 P. Renouard, Bibliographie des impressions et des ouvres de Josse Badius Ascensius, imprimeur et humaniste, 1462-1535, vol. 2 (Paris, 1908), 173, item 6. Renouard has as item 5 another undated printing containing only In principe requiri doctrinam and Cum principibus maxime philosophum debere disputare.

24 The digital copy held at the National Library of Romania (shelf mark XVI/II 127; available online at http://www.manuscriptorium.com) shows no differences either. Besides this copy and those mentioned by Renouard in the Bibliothèque de la Ville de Lemans, in Limoges, and Universiteitsbibliotheek of Ghent, there is another one in the Centrale Bibliotheek of Rotterdam (Erasmuszaal 11 E 1, dated 1510[!] in the catalogue). 
The second notable difference is that OPAsc is made up of three signatures (a1r-a8v, b1r-b8v, c1r-c8v) with continuous foliation, and therefore seems to have been composed from a single manuscript. OPFrob, on the other hand, shows interesting issues that tell an unlikely story:

[1] How to tell a flatterer from a friend (Quo pacto possis adulatorem ab amico dignoscere) and How to profit by one's enemies (Quo pacto quis efficiat ut ex inimicis capiat utilitatem) have their own signatures (A1r-A6v, B1r-B8v, C1r-C8v, and D1r-D5v) and, strangely, How to tell a flatterer from a friend has pagination (one number per page) while How to profit by one's enemies has foliation (only numbered on the rectos).

[2] Moreover, the second set of texts, which coincides in order with those in $O P A s c$, starts with a blank folio and has its own signatures (a1r-a8v, b1r-b8v, c1r-c4v, and $\mathrm{d} 1 \mathrm{r}-\mathrm{d} 5 \mathrm{v})$ as well as independent foliation $(1 \mathrm{r}-25 \mathrm{v})$. Therefore, it can be inferred that the two texts at the beginning of OPFrob were included when the composition of the titles that coincide with $O P A s c$ was well advanced.

Notwithstanding the previous point, there is a striking particularity in $O P A s c$ that suggests that both OPAsc and OPFrob were composed under similar circumstances and with similar expectations; that is, it appears that Badius awaited further translations of the Moralia in order to include them in the whole, and that those translations did not arrive, as the results attest. This can be seen in how On love of wealth (De cupiditate divitiarum) is printed in OPAsc: instead of respecting the text box and the justification of the text - as with the other opuscules in the volume - it presents random line breaks, and each line is headed by a capital letter, as if it were written in verse (PLATES 4 and 5). This spreads the book out over three full signatures with the same number of sheets, and without presenting an excessive number of endpapers.

Another remarkable difference between OPAsc and OPFrob lies in their approach to the use of marginalia (a full list in Appendix 3, below). While there are plenty of these in OPFrob, OPAsc only includes them in To an uneducated ruler (In principe requiri doctrinam) and A philosopher ought to converse especially with men in power (Cum principibus maxime philosophum debere disputare). When these two works are compared in both editions, however, it is clear that they were composed following two copies of the same manuscript (if not actually the same manuscript). Any other possibility, such as Badius having copied the 
Frobeniana, does not make sense: there is no reason why he would copy only the marginalia of two opuscules when he could have included all of them. The opposite possibility (namely, Froben having copied the Ascensiana) is equally unlikely due to the detail of the marginalia throughout the Frobeniana.

An exhaustive collation of OPAsC and the OPFrob, and their comparison with the critical edition of Koster for ASD as compiled in Appendix 2 , only reinforces the idea that the texts included in both editions were composed using, if not the exact same manuscript, quite a reliable copy of the same translation. The differences are mainly due to orthographic practices in Latin, poor readings of abbreviations - mundo vs. numero, impium instead of ipsum, acceperunt instead of acceperit, parum instead of rarum, quatinus instead of quatenus - and unavoidable typos that originated in the printing process; thus it could easily be concluded that the differences between opuscules present in OPAsc and OPFrob are minimal. It will suffice to point out that both editions even present an omissio ex homoioteleuto (line skip) in the same passage: "non sitientes 〈bibunt neque esurientes edunt, etiam ea, quae sitientes atque esurientes sumpserant" (ASD 4.2, 252, 1. 30-32).

\section{Conclusion}

In sum, the presentation of this new, partial edition of the Opuscula Plutarchi printed by Badius Ascensius' press between 1513 and July 1514 allows us to shed light on some fundamental aspects related to the editorial history of Erasmus' translation of the Moralia. The hypothesis presented in these pages can be summarized as follows: although it is not directly stated in Erasmus' letters, at some point between the end of 1512 and the summer of 1513, Franz Birckmann gave Badius Ascensius a copy of six Moralia translated by Erasmus with their publication in mind. As the letter from Erasmus to Andrea Ammonio suggests, Erasmus was aware of this fact. That being so, Birckmann gave to Iodocus Badius Ascensius and to Johannes Froben copies of Advice about keeping well (De tuenda bona valetudine praecepta), To an uneducated ruler (In principe requiri doctrinam), A philosopher ought to converse especially with men in power (Cum principibus maxime philosophum debere disputare), Whether affections of the soul are worse than those of the body (Utrum graviores sint animi morbi q[uam] 
corporis), Is the saying "live in obscurity" right? (Num recte dictum sit $\Lambda \alpha \dot{\theta \varepsilon} \beta \hat{\imath} \sigma \alpha \varsigma$, id est, Sic vive ut nemo te sentiat vixisse), and On love of wealth (De cupiditate divitiarum) to be printed. Considering the number of texts handed over, this was probably done with the promise of providing the printers with yet two more translations of Plutarch - How to tell a flatterer from a friend (Quo pacto possis adulatorem ab amico dignoscere or De discrimine adulatoris et amici) and How to profit by one's enemies (Quo pacto quis efficiat ut ex inimicis capiat utilitatem) together with an enlarged and revised version of the Adagia.

Birckmann on his own, though most likely with Erasmus' approval, gave these last two promised manuscripts to Froben but not to Badius. As Beatus Rhenanus' letters to Hummelberger do not have any information about this fact, nor about the new edition of the Adagia which Badius was supposed to print, until September 1514, it is possible that Badius became aware of the situation either through another informant or by inferring it after Birckmann failed to appear with the promised manuscripts. In either case, the news arrived at Badius' press while the manuscript of the Moralia was being composed and the extra translations were still expected.

As seems to have been the case with Froben's editio princeps, Badius probably intended to include the two latest translations at the end of the volume. When Froben discovered that the two new opuscula accounted for almost half the entire volume and that they had a dedicatory epistle to Henry VIII and Thomas Wolsey, he realized that it made no sense to place them after the shorter works. He solved this problem with new infolios and two different signatures: capitals for the new opuscula (sig. A1v-D5v) and lower-cases for the next six (sig. a1r-d5v). Badius probably had also reserved space at the end of the infolio and, upon receiving the news that Froben had two new opuscula and he did not, opted for the very inelegant solution of introducing random line breaks to fill as much space on the paper as possible. This, together with the elision of marginalia in four of the six Moralia, allowed him to finish the work much faster than Froben, and not lose his investment of time, ink, and paper.

Universidade da Coruña j.ledo@udc.es 


\section{Appendices}

A.J. Koster published his magnificent edition of Erasmus' translations of Plutarch's Moralia in ASD 4.2. The editions considered by Koster for his critical edition were the following:
$A \quad$ ed. princ., Basel, Ioh. Frobenius, mense Augusto 1514
$B \quad$ ed. Basel, Ioh. Frobenius, mense Maio 1516
$C \quad$ ed. Basel, Ioh. Frobenius, mense Iulio 1518
$D \quad$ ed. Basel, Ioh. Frobenius, mense Iunio 1519
$E \quad$ ed. Basel, Ioh. Frobenius, mense Septembri 1520
$B A S$ ed. Basel, H. Frobenius et N. Episcopius, Omnia opera, 1540
$L B \quad$ ed. Leiden, P. vander Aa, Opera omnia, 1703

As I have argued above, $A$ should no longer be considered as the editio princeps of Erasmus' Plutarchi opuscula; that honour should now go to the editio Parisina (Iod. Badius Ascensius, circa 1513). Although, in my opinion, the opuscules contained in both volumes were composed using closely similar copies, if not the same copy, they present some variants and traits of interest.

The aim of the three following appendices is to highlight those differences and to favour further research. Thus, [1] I have rebuilt the table of contents of both volumes, [2] I have compared OPAsc with the one in ASD, and I have recorded every difference and compared it to OPFroba direct comparison between OPAsc and OPFrob would show even more differences useful for research on both editions, but not so much for the present critical edition -, and [3] I have provided a full list of marginalia in OPAsc and OPFrob. I believe that the coincidence of the marginalia of In principe requiri doctrinam and Cum principibus maxime philosophum debere disputare requires further research on how both texts were composed - research that exceeds, once more, the aim of these pages. 


\section{Appendix 1. Table of contents of both editions}

\begin{tabular}{|c|c|}
\hline OPAsc & OPFrob \\
\hline & $\begin{array}{l}\text { Invictissimo Anglorum regi Henrico Octavo } \\
\text { Erasmus Rote[r]odammus, S.D., p. 1-2 (sig. } \\
\text { A1v-A2r). }\end{array}$ \\
\hline & $\begin{array}{l}\text { Quo pacto possis adulatorem ab amico } \\
\text { dignoscere Plutarchi, Erasmo interprete, } \\
\text { p. } 2-21 \text { (sig. A2r-C7r). }\end{array}$ \\
\hline & Blank page (sig. C7v). \\
\hline & $\begin{array}{l}\text { Reverendissimo in Christo Patri D. Thomae } \\
\text { episcopo Lyncolniensi sereniss[imi] } \\
\text { Anglorum regis magno elemosynario. } \\
\text { Erasmus Roterodamus S.D., } 22 \text { (sig. C8r). }\end{array}$ \\
\hline & $\begin{array}{l}\text { Quo pacto quis efficiat ut ex inimicis capiat } \\
\text { utilitatem, Plutarchi Chaeroniensis Erasmo } \\
\text { Roterodamo interprete, f. } 22 \mathrm{v}-27 \mathrm{v} \\
\text { (sig. C8v-D5v). } \\
\text { The running head ("Plutarchi De utilitate") } \\
\text { is over the title. (PLATE 6) }\end{array}$ \\
\hline & Two blank pages (sig. D6r-D6v or a1r-a1v). \\
\hline $\begin{array}{l}\text { Putarchi [sic] De tuenda bona valetudine } \\
\text { praecepta Erasmo interprete. Tò } \pi \rho o ́ \sigma \omega \pi \alpha \text {. } \\
\text { Moschion et Xeusippus, f. } 2 \mathrm{r}-12 \mathrm{r} \\
\text { (sig. a2r-b4r). }\end{array}$ & $\begin{array}{l}\text { Plutarchi De tuenda bona valetudine } \\
\text { praecepta Erasmo interprete } \tau \grave{\alpha} \pi \rho{ }^{\sigma} \sigma \omega \pi \alpha \\
\text { Moschion et Xeusippus, f. } 2 \mathrm{r}-13 \mathrm{v} \\
(\text { sig. a2r-b5v). }\end{array}$ \\
\hline $\begin{array}{l}\text { The running head ("de tuenda bo. vale") is } \\
\text { over the title. (PLATE 7) }\end{array}$ & $\begin{array}{l}\text { The running head ("de tuenda bo. vale") is } \\
\text { over the title. (PLATE } 8 \text { ) }\end{array}$ \\
\hline $\begin{array}{l}\text { In principe requiri doctrinam Plutarchi } \\
\text { commentarium, Erasmo Roterodamo } \\
\text { interprete, f. } 12 \mathrm{r}-14 \mathrm{r} \text { (sig. b4r-b6r). }\end{array}$ & $\begin{array}{l}\text { In principe requiri doctrinam Plutarchi } \\
\text { commentarium, Erasmo Roterodamo } \\
\text { interprete, f. } 13 \mathrm{v}-16 \mathrm{r} \text { (sig. b5v-b8r). }\end{array}$ \\
\hline $\begin{array}{l}\text { Cum principibus maxime philosophum } \\
\text { debere disputare Plutarchi, Erasmo } \\
\text { interprete, f. } 14 \mathrm{r}-16 \mathrm{r} \text { (sig. b6r-b8r). }\end{array}$ & $\begin{array}{l}\text { Cum principibus maxime philosophum } \\
\text { debere disputare } \text { Plutarchi, Erasmo } \\
\text { interprete, f. } 16 \mathrm{r}-18 \mathrm{v} \text { (sig. b8r-c2v). }\end{array}$ \\
\hline $\begin{array}{l}\text { Vtrum grauiores sint animi morbi q[uam] } \\
\text { corporis, Plutarchus Erasmo interprete, } \\
\text { f. } 16 \mathrm{v}-17 \mathrm{v} \text { (sig. b8v-c1r). } \\
\text { The running head ("Plutarchi Cheronei") } \\
\text { should not be on the title page. (PLATE 9) }\end{array}$ & $\begin{array}{l}\text { Vtrum grauiores sint animi morbi q[uam] } \\
\text { corporis. Plutarchus Erasmo interprete, } \\
\text { f. } 18 \mathrm{v}-20 \mathrm{r}(\mathrm{sig} . \mathrm{c} 2 \mathrm{v}-\mathrm{c} 4 \mathrm{r}) \text {. }\end{array}$ \\
\hline $\begin{array}{l}\text { Num recte dictu[m] sit } \Lambda \alpha \dot{\theta} \varepsilon \mathrm{B} \mathrm{B} \omega ́ \sigma \alpha \sigma \\
\mathrm{i}[\mathrm{d} \text { est]., Sic viue vt nemo te sentiat vixisse, } \\
\text { f. } 17 \mathrm{v}-19 \mathrm{r} \text { ( } \mathrm{sig} . \mathrm{c} 1 \mathrm{v}-\mathrm{c} 3 \mathrm{r} \text { ). }\end{array}$ & 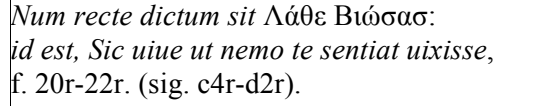 \\
\hline
\end{tabular}

\footnotetext{
${ }^{1}$ An edition of Christophe de Longueil's translation of How to profit by one's enemies

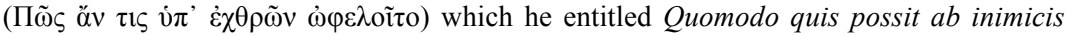
iuvari, with Erasmus' handwritten translation reproduced on facing pages, titled Quo pacto quis efficiat ut ex inimicis capiat utilitatem (ca. 1512), in R. Aulotte, "Une rivalité d'humanistes. Érasme et Longueil, traducteurs de Plutarque", Bibliothèque d'Humanisme et Renaissance 30.3 (1968), 549-573. The manuscript is extant at Basel, Universitätsbibliothek, ms. AN. VI. I.
} 


\begin{tabular}{|l|l|}
\hline $\begin{array}{l}\text { Plutarchus, De cupiditate diuitiarum, } \\
\text { Desi[derio] Eras[mo] Rote[rodamo] } \\
\text { interprete, f. 19r-24r (sig. c3r-c8r). }\end{array}$ & $\begin{array}{l}\text { Plutarchus, De cupiditate diuitiarum } \\
\text { Desiderio Erasmo Roterodamo interprete, } \\
\text { f. 22v-25v (sig. d2v-d5v). } \\
\text { Same as above, the running head ("Plutarchi } \\
\text { Chaeronei") is over the title. (PLATE 10) }\end{array}$ \\
\hline $\begin{array}{l}\text { The volume has neither colophon nor } \\
\text { register of signatures. }\end{array}$ & $\begin{array}{l}\text { Colophon: "Basileae in aedibus Ioannis } \\
\text { Frobenij Hammelburgensis, mense Augusto, } \\
\text { Anno domini millesimo quingentesimo } \\
\text { decimoquarto", f. 25v (sig. d5v). } \\
\text { There is no register of signatures in the } \\
\text { volume. }\end{array}$ \\
\hline
\end{tabular}


Appendix 2. Complete list of variants between ASD and OPAsc

\begin{tabular}{|c|c|c|c|}
\hline $\begin{array}{l}\text { ASD IV.2 } \\
\text { (page; line) }\end{array}$ & OPAsc & $\begin{array}{l}\text { OPFrob } \\
\text { ('A' in } A S D \text { IV.2) }\end{array}$ & $\begin{array}{l}\text { ASD IV.2 } \\
\text { Text }\end{array}$ \\
\hline \multicolumn{4}{|c|}{$\begin{array}{l}\text { [III.] De tuenda bona valetudine praecepta Erasmo interprete. Tà } \pi \rho o ́ \sigma \omega \pi \alpha . \\
\text { Moschion et Xeusippus }\end{array}$} \\
\hline $189 ; 1-4$ & $\begin{array}{l}\text { Putarchi De tuenda } \\
\text { bona valetudine } \\
\text { praecepta Erasmo } \\
\text { interprete. Tò } \\
\pi \rho{ }^{\circ} \sigma \omega \pi \alpha . \text { Moschion } \\
\text { et Xeusippus }\end{array}$ & $\begin{array}{l}\text { Plutarchi De tuenda } \\
\text { bona valetudine } \\
\text { praecepta Erasmo } \\
\text { interprete. Tò } \\
\pi \rho o ́ \sigma \omega \pi \alpha . \text { Moschion } \\
\text { et Xeusippus }\end{array}$ & $\begin{array}{l}\text { Plutarchi } \\
\text { Chaeronensis De } \\
\text { tuenda bona sanitate } \\
\text { precepta Erasmo } \\
\text { Roterodamo } \\
\text { interprete. Moschion } \\
\text { et Zeuxippus }\end{array}$ \\
\hline $189 ; 8$ & praeberem & praeberem & preberem \\
\hline $189 ; 9$ & medica vir ille & medica vir ille & $\begin{array}{l}\text { medica ille vir } \\
\text { [transposed] }\end{array}$ \\
\hline $189 ; 11$ & aequandus & aequandus & equandus \\
\hline $189 ; 15$ & ausos esse nos & ausos esse nos & ausos nos esse \\
\hline $189 ; 25$ & musicaeque & musicae & musicaeque \\
\hline $190 ; 30-31$ & $\begin{array}{l}\text { de mundo } \\
\text { disciplinarum } \\
\text { liberalium }\end{array}$ & $\begin{array}{l}\text { de mundo } \\
\text { disciplinarum } \\
\text { liberalium }\end{array}$ & $\begin{array}{l}\text { de numero } \\
\text { disciplinarum } \\
\text { liberalium }\end{array}$ \\
\hline $190 ; 47$ & $\begin{array}{l}\text { Rursum si ea quae } \\
\text { foras vergunt }\end{array}$ & $\begin{array}{l}\text { Rursum si ea que } \\
\text { foras vergunt }\end{array}$ & $\begin{array}{l}\text { Rursus si ea quae } \\
\text { foras vergunt }\end{array}$ \\
\hline $190 ; 54$ & quos aegrotantibus & quos aegrotantibus & quos egrotantibus \\
\hline $191 ; 59$ & necessum erit & necessum erit & necessum sit \\
\hline $191 ; 61$ & aestate & aestate & estate \\
\hline $192 ; 78$ & $\begin{array}{l}\text { quorum de mundo } \\
\text { Titus erat imperator }\end{array}$ & $\begin{array}{l}\text { quorum de numero } \\
\text { Titus erat imperator }\end{array}$ & $\begin{array}{l}\text { quorum de numero } \\
\text { Titus erat Imperator }\end{array}$ \\
\hline $192 ; 83$ & $\begin{array}{l}\text { apparant conuiuio } \\
\text { accipere aut futurum } \\
\text { est }\end{array}$ & $\begin{array}{l}\text { apparant conuiuio } \\
\text { accipere aut futurum } \\
\text { est }\end{array}$ & $\begin{array}{l}\text { apparent conuiuio } \\
\text { accipere aut quibus } \\
\text { futurum est }\end{array}$ \\
\hline $192 ; 87-88$ & $\begin{array}{l}\text { inter inuitatiunculas } \\
\text { illorum, te impium } \\
\text { intra mediocritatem }\end{array}$ & $\begin{array}{l}\text { inter inuitatiunculas } \\
\text { illorum te ipsum intra } \\
\text { mediocritatem }\end{array}$ & $\begin{array}{l}\text { inter inuitatiunculas } \\
\text { illorum te ipsum intra } \\
\text { mediocritatem }\end{array}$ \\
\hline $192 ; 95-96$ & $\begin{array}{l}\text { Philippus submisit, } \\
\text { qui singulos amicos } \\
\text { admoneret }\end{array}$ & $\begin{array}{l}\text { Philippus submisit, } \\
\text { qui singulos amicos } \\
\text { admoneret }\end{array}$ & $\begin{array}{l}\text { Philippus submisit, } \\
\text { qui singulos } \\
\text { admoneret }\end{array}$ \\
\hline $192 ; 103$ & praesentibus & praesentibus & presentibus \\
\hline $193 ; 118-119$ & $\begin{array}{l}\text { simulque voret } \\
\text { opsonia. Adduxeram } \\
\text { autem }\end{array}$ & $\begin{array}{l}\text { simulque voret } \\
\text { opsonia. Adduxeram } \\
\text { autem }\end{array}$ & $\begin{array}{l}\text { simulque voret } \\
\text { obsonia. Addux }\langle\text { it }\rangle \\
\text { autem }\end{array}$ \\
\hline
\end{tabular}

\footnotetext{
${ }^{2}$ The distinction between Xeusippus and Zeuxippus [sic] is omitted from now on, although it is consistent throughout the text.
} 


\begin{tabular}{|c|c|c|c|}
\hline $193 ; 122$ & $\begin{array}{l}\text { hominibus Rhiglum } \\
\text { pacratiasten } \\
\text { commemoraueram }\end{array}$ & $\begin{array}{l}\text { hominibus Rhiglum } \\
\text { pancratiasten } \\
\text { commemoraueram }\end{array}$ & $\begin{array}{l}\text { hominibus Rhiglum } \\
\text { pancratiasten } \\
\text { commemorau〈it }\end{array}$ \\
\hline $193 ; 125$ & paedagogica & paedagogica & pedagogica \\
\hline $193 ; 133$ & $\begin{array}{l}\text { Nam quod natura } \\
\text { delectat }\end{array}$ & $\begin{array}{l}\text { Nam quod natura } \\
\text { delectat }\end{array}$ & $\begin{array}{l}\text { Nam quod natura } \\
\text { delectet }\end{array}$ \\
\hline $194 ; 139$ & $\begin{array}{l}\text { Caeterum qui iam } \\
\text { acceperunt }\end{array}$ & $\begin{array}{l}\text { Caeterum, qui iam } \\
\text { acceperit }\end{array}$ & $\begin{array}{l}\text { Caeterum, qui iam } \\
\text { acceperit }\end{array}$ \\
\hline $194 ; 147$ & $\begin{array}{l}\text { uti corpus adigas cum } \\
\text { cibis habere } \\
\text { conuicium }\end{array}$ & $\begin{array}{l}\text { uti corpus adigas cum } \\
\text { cibis habere } \\
\text { conuicium }\end{array}$ & $\begin{array}{l}\text { vti corpus cum cibis } \\
\text { adigas habere } \\
\text { commercium } \\
\text { [adigas cum cibis has } \\
\text { been transposed] }\end{array}$ \\
\hline $194 ; 154$ & $\begin{array}{l}\text { Caeterum Phryne } \\
\text { Laidiue persoluto } \\
\text { argento }\end{array}$ & $\begin{array}{l}\text { Caeterum Phryne } \\
\text { Laidiue persoluto } \\
\text { argento }\end{array}$ & $\begin{array}{l}\text { Caeterum Phrynae } \\
\text { Laidiue persoluto } \\
\text { argento }\end{array}$ \\
\hline $194 ; 155$ & $\begin{array}{l}\text { Porro magnum sit ad } \\
\text { mirum }\end{array}$ & $\begin{array}{l}\text { Porro magnum est ad } \\
\text { mirum }\end{array}$ & $\begin{array}{l}\text { Porro magnum est ad } \\
\text { mirum }\end{array}$ \\
\hline $194 ; 160-161$ & $\begin{array}{l}\text { Iam vero illius } \\
\text { cupiditates, quae } \\
\text { praeposterae ab } \\
\text { animo scatent in } \\
\text { corpus coguntque } \\
\text { affectibus obsequi et } \\
\text { inseruire nulla ratione } \\
\text { fieri potest }\end{array}$ & $\begin{array}{l}\text { Iam vero illius } \\
\text { cupiditates, quae } \\
\text { praeposterae ab } \\
\text { animo scatent in } \\
\text { corpus coguntque } \\
\text { affectibus obsequi et } \\
\text { inseruire nulla ratione } \\
\text { fieri potest }\end{array}$ & $\begin{array}{l}\text { Iam vero cupiditates, } \\
\text { quae prepostere ab } \\
\text { animo scatent in } \\
\text { corpus congutque } \\
\text { illius affectibus } \\
\text { obsequi et inseruire, } \\
\text { nulla ratione fieri } \\
\text { potest } \\
\text { [illius } \text { transposed] }\end{array}$ \\
\hline $194 ; 166$ & praebent animo & praebent animo & prebent animo \\
\hline $194 ; 167-168$ & $\begin{array}{l}\text { hae nimirum et } \\
\text { stupidae sunt }\end{array}$ & $\begin{array}{l}\text { hae nimirum et } \\
\text { stupidae sunt }\end{array}$ & $\begin{array}{l}\text { eae nimirum et } \\
\text { stupidae sunt }\end{array}$ \\
\hline $194 ; 168$ & $\begin{array}{l}\text { Quoties igitur parum } \\
\text { aliquod aut nobile cibi } \\
\text { genus fruendum } \\
\text { appositum fuit }\end{array}$ & $\begin{array}{l}\text { Quoties igitur rarum } \\
\text { ialiquod aut nobile cib } \\
\text { genus fruendum } \\
\text { appositum fuit }\end{array}$ & $\begin{array}{l}\text { Quoties igitur rarum } \\
\text { ialiquod aut nobile cibi } \\
\text { genus fruendum } \\
\text { appositum fuerit }\end{array}$ \\
\hline $194 ; 174$ & desyderanti & desideranti & desideranti \\
\hline $194 ; 176$ & etiam si & etiam si & etsi \\
\hline $195 ; 185$ & nos coniicias & nos coniicias & nos conicias \\
\hline $195 ; 188$ & $\begin{array}{l}\text { et tumultum ac } \\
\text { perluuium }\end{array}$ & $\begin{array}{l}\text { et tumultum ac } \\
\text { perluuium }\end{array}$ & $\begin{array}{l}\text { ac profluuium et } \\
\text { tumultum }\end{array}$ \\
\hline $195 ; 189$ & opsoniorum & opsoniorum & obsoniorum \\
\hline $195 ; 194$ & opsonia & opsonia & obsonia \\
\hline $195 ; 198$ & $\begin{array}{l}\text { Attellanis } \\
\text { intemperantiam }\end{array}$ & $\begin{array}{l}\text { Attellanis } \\
\text { intemperantiam }\end{array}$ & $\begin{array}{l}\text { Atellanis } \\
\text { intemperantiam }\end{array}$ \\
\hline $195 ; 198-199$ & $\begin{array}{l}\text { ad voluptatem excites } \\
\text { atque irrites an } \\
\text { gustum odorius et } \\
\text { lauticiis prouoces }\end{array}$ & $\begin{array}{l}\text { ad uoluptatem excites } \\
\text { atque irrites an } \\
\text { gustum odoribus et } \\
\text { lauticiis prouoces }\end{array}$ & $\begin{array}{l}\text { ad voluptatem excites } \\
\text { an gustum odoribus et } \\
\text { lauticiis prouoces }\end{array}$ \\
\hline $196 ; 203$ & $\begin{array}{l}\text { de multitudine ac } \\
\text { magnitudine }\end{array}$ & $\begin{array}{l}\text { de multitudine ac } \\
\text { magnitudine }\end{array}$ & $\begin{array}{l}\text { de multitudine et } \\
\text { magnitudine }\end{array}$ \\
\hline $196 ; 218$ & $\begin{array}{l}\text { Nam verissime quis } \\
\text { dixerit }\end{array}$ & $\begin{array}{l}\text { Nam uerissime quis } \\
\text { dixerit }\end{array}$ & $\begin{array}{l}\text { 〈Sed }\rangle \text { verissime quis } \\
\text { dixerit }\end{array}$ \\
\hline
\end{tabular}




\begin{tabular}{|c|c|c|c|}
\hline $196 ; 218-219$ & $\begin{array}{l}\text { bonam valetudinem } \\
\text { maxime diuinum } \\
\text { longeque }\end{array}$ & $\begin{array}{l}\text { bonam valetudinem } \\
\text { maxime diuinum } \\
\text { longeque }\end{array}$ & $\begin{array}{l}\text { bonam valetudinem } \\
\text { diuinum longeque }\end{array}$ \\
\hline $196 ; 222$ & synceraque & synceraque & sinceraque \\
\hline $196 ; 236$ & $\begin{array}{l}\text { non in tempore } \\
\text { sumptam }\end{array}$ & $\begin{array}{l}\text { non in tempore } \\
\text { sumptam }\end{array}$ & $\begin{array}{l}\text { non in tempore } \\
\text { sumptum }\end{array}$ \\
\hline $196 ; 238$ & praeclara negocia & praeclara negocia & preclara negocia \\
\hline $196 ; 239$ & ut dolor quidem & ut dolor quidem & vt dolor quidam \\
\hline $197 ; 251-252$ & opsoniorum & opsoniorum & obsoniorum \\
\hline $197 ; 255$ & aestus & aestus & estus \\
\hline $197 ; 259$ & $\begin{array}{l}\text { humorum abundantia } \\
\text { iam ante collecta } \\
\text { corpus exhibent ac } \\
\text { tradunt }\end{array}$ & $\begin{array}{l}\text { humorum abundantia } \\
\text { iam ante collecta } \\
\text { corpus exhibent ac } \\
\text { tradunt }\end{array}$ & $\begin{array}{l}\text { humorum abundantia } \\
\text { iam ante collecta } \\
\text { corpus exhibet ac } \\
\text { tradit }\end{array}$ \\
\hline $197 ; 262$ & coenum & coenum & caenum \\
\hline $197 ; 263$ & $\begin{array}{l}\text { Proinde cauendum } \\
\text { est, ne sicuti boni } \\
\text { naucleri }\end{array}$ & $\begin{array}{l}\text { Proinde cauendum } \\
\text { est, ne sicuti boni } \\
\text { naucleri }\end{array}$ & $\begin{array}{l}\text { Proinde cauendum } \\
\text { est, ne sicuti }\langle\text { mali〉 } \\
\text { naucleri }\end{array}$ \\
\hline $198 ; 270$ & praesentitur & praesentitur & presentitur \\
\hline $198 ; 272$ & Immo plaerique & Immo plaerique & Imo plerique \\
\hline $198 ; 272$ & $\begin{array}{l}\text { praenuncient } \\
\text { praecurrantque }\end{array}$ & $\begin{array}{l}\text { praenuncient } \\
\text { praecurrantque }\end{array}$ & $\begin{array}{l}\text { prenuncient } \\
\text { precurrantque }\end{array}$ \\
\hline $198 ; 276$ & adhaerent & adhaerent & adherent \\
\hline $198 ; 277-278$ & $\begin{array}{l}\text { ad lectulum quietem } \\
\text { pertrahat, tamen alii } \\
\text { gulae deliciarum } \\
\text { intemperantia in } \\
\text { balnea se coniciunt }\end{array}$ & $\begin{array}{l}\text { ad lectulum quietem } \\
\text { pertrahat, tamen alii } \\
\text { gulae deliciarum } \\
\text { intemperantia in } \\
\text { balnea se coniciunt }\end{array}$ & $\begin{array}{l}\text { ad lectulum quietem } \\
\text { pertrahat, tum alii } \\
\text { gulae deliciarum } \\
\text { intemperantia in } \\
\text { balnea se coniciunt }\end{array}$ \\
\hline $198 ; 290$ & $\begin{array}{l}\text { agas quam tractus ad } \\
\text { balneum }\end{array}$ & $\begin{array}{l}\text { agas quam tractus ad } \\
\text { balneum }\end{array}$ & $\begin{array}{l}\text { agas quam vt tractus } \\
\text { ad balneum }\end{array}$ \\
\hline $199 ; 310$ & $\begin{array}{l}\text { ita condimentum esse } \\
\text { optimum appositi cibi }\end{array}$ & $\begin{array}{l}\text { ita condimentum esse } \\
\text { optimum appositi cibi }\end{array}$ & $\begin{array}{l}\text { ita condimentum } \\
\text { optimum esse appositi } \\
\text { cibi [transposed] }\end{array}$ \\
\hline $199 ; 314$ & haec & haec & hec \\
\hline $199 ; 318$ & in aedes irrumpant & in aedes irrumpant & in edes irrumpant \\
\hline $199 ; 320$ & obsonia & obsonia & opsonia \\
\hline $200 ; 331$ & caelo & caelo & celo \\
\hline $200 ; 334$ & perfluuio & perfluuio & profluuio \\
\hline $200 ; 341$ & $\begin{array}{l}\text { praecipere ac } \\
\text { praecauere }\end{array}$ & $\begin{array}{l}\text { praecipere ac } \\
\text { praecauere }\end{array}$ & $\begin{array}{l}\text { precipere ac } \\
\text { precauere }\end{array}$ \\
\hline $200 ; 343$ & praeter & praeter & preter \\
\hline $200 ; 346$ & inaequalis & inaequalis & inequalis \\
\hline $200 ; 352-353$ & $\begin{array}{l}\text { vt facile } \\
\text { commoueantur }\end{array}$ & $\begin{array}{l}\text { ut facile } \\
\text { commoueantur }\end{array}$ & $\begin{array}{l}\text { vt et facile } \\
\text { commoueantur }\end{array}$ \\
\hline $200 ; 353$ & $\begin{array}{l}\text { lachrymanturque ac } \\
\text { moerent }\end{array}$ & $\begin{array}{l}\text { lachrymanturque ac } \\
\text { moerent }\end{array}$ & $\begin{array}{l}\text { lachrymenturque ac } \\
\text { moereant }\end{array}$ \\
\hline $200 ; 356$ & consyderent & considerent & Considerent \\
\hline $200 ; 360$ & $\begin{array}{l}\text { morbi causam, non ita } \\
\text { sane vti sophistice } \\
\text { praeterque rem de } \\
\text { densitatibus }\end{array}$ & $\begin{array}{l}\text { morbi causam, non ita } \\
\text { sane uti sophistice } \\
\text { praeterque rem de } \\
\text { densitatibus }\end{array}$ & $\begin{array}{l}\text { morbi causam non ita, } \\
\text { vt sophistice } \\
\text { preterque rem de } \\
\text { densitatibus }\end{array}$ \\
\hline
\end{tabular}




\begin{tabular}{|c|c|c|c|}
\hline $200 ; 363$ & praecipue & praecipue & precipue \\
\hline $200 ; 364$ & $\begin{array}{l}\text { cum in febrim } \\
\text { inciderit }\end{array}$ & $\begin{array}{l}\text { cum in febrim } \\
\text { inciderit }\end{array}$ & $\begin{array}{l}\text { quum in febrim } \\
\text { inciderit }\end{array}$ \\
\hline $200 ; 367-368$ & desyderet & desideret & desideret \\
\hline $201 ; 378$ & haec & haec & hec \\
\hline $201 ; 379$ & aegritudinum & aegritudinum & egritudinum \\
\hline $201 ; 380$ & $\begin{array}{l}\text { Proinde praeclare } \\
\text { dictum est illud }\end{array}$ & $\begin{array}{l}\text { Proinde praeclare } \\
\text { dictum est illud }\end{array}$ & $\begin{array}{l}\text { Proinde preclarum } \\
\text { dictum est illud }\end{array}$ \\
\hline $202 ; 388$ & praecepta & praecepta & precepta \\
\hline $202 ; 390-391$ & palaestricum & palaestricum & palestricum \\
\hline $202 ; 399$ & faecis & faecis & fecis \\
\hline $202 ; 407$ & inaequalis ille spiritus & inaequalis ille spiritus & $\begin{array}{l}\text { inaequalis illae } \\
\text { spiritus }\end{array}$ \\
\hline $202 ; 411$ & aequabilem & aequabilem & equabilem \\
\hline $202 ; 412$ & $\begin{array}{l}\text { Sit autem hic factus } \\
\text { modus }\end{array}$ & $\begin{array}{l}\text { Sit autem hic factus } \\
\text { modus }\end{array}$ & $\begin{array}{l}\text { Sit autem hic frictus } \\
\text { modus }\end{array}$ \\
\hline $202 ; 413$ & $\begin{array}{l}\text { Quisquis adhuc } \\
\text { composuerit }\end{array}$ & $\begin{array}{l}\text { Quisquis adhuc } \\
\text { composuerit }\end{array}$ & $\begin{array}{l}\text { Quisquis ad hunc } \\
\text { modum composuerit }\end{array}$ \\
\hline $202 ; 422$ & quaeras & quaeras & queras \\
\hline $202 ; 428$ & praemiis & praemiis & premiis \\
\hline $202 ; 433$ & $\begin{array}{l}\text { gutturi infixa coepit } \\
\text { exerceri }\end{array}$ & $\begin{array}{l}\text { gutturi infixa coepit } \\
\text { exerceri }\end{array}$ & $\begin{array}{l}\text { gutturi infixa coepit } \\
\text { exercere }\end{array}$ \\
\hline $202 ; 435$ & Ac spina quidem & At spina quidem & At spina quidem \\
\hline $204 ; 448$ & haereant & haereant & hereant \\
\hline $204 ; 461$ & cum apponuntur & cum apponuntur & cum apponantur \\
\hline $204 ; 463$ & plaeraque & plaeraque & pleraque \\
\hline $204 ; 468$ & $\begin{array}{l}\text { carnium esum } \\
\text { desyderet }\end{array}$ & $\begin{array}{l}\text { carnium esum } \\
\text { desyderet }\end{array}$ & $\begin{array}{l}\text { carnium esum } \\
\text { desideret }\end{array}$ \\
\hline $204 ; 472$ & vt praeter naturam sit & ut praeter naturam sit & vt preter naturam sit \\
\hline $204 ; 475$ & aliisque opsoniis & aliisque opsoniis & aliisque obsoniis \\
\hline $205 ; 491$ & aestuant & aestuant & estuant \\
\hline $205 ; 497$ & $\begin{array}{l}\text { minuendus est etiam } \\
\text { cibus }\end{array}$ & $\begin{array}{l}\text { minuendus est etiam } \\
\text { cibus }\end{array}$ & minuendus est cibus \\
\hline $205 ; 497$ & subtrahendum & subtrahendum & substrahendum \\
\hline $206 ; 512$ & $\begin{array}{l}\text { At Minos et tybiam } \\
\text { submouit a sacris }\end{array}$ & $\begin{array}{l}\text { At Minos et tybiam } \\
\text { submouit a sacris }\end{array}$ & $\begin{array}{l}\text { Ac Minos et tibiam } \\
\text { summouit a sacris }\end{array}$ \\
\hline $206 ; 513$ & tybiis & tybiis & tibiis \\
\hline $206 ; 514$ & laedatur & laedatur & ledatur \\
\hline $206 ; 519$ & abiiciet & abiiciet & abiciet \\
\hline $206 ; 523$ & Graecus & Graecus & Grecus \\
\hline $206 ; 527$ & $\begin{array}{l}\text { oculis arrodebant } \\
\text { bellaria }\end{array}$ & $\begin{array}{l}\text { oculis arrodebant } \\
\text { bellaria }\end{array}$ & $\begin{array}{l}\text { oculis arrodebat } \\
\text { bellaria }\end{array}$ \\
\hline $206 ; 530$ & $\begin{array}{l}\text { Caeterum quum } \\
\text { vndique }\end{array}$ & $\begin{array}{l}\text { Caeterum quum } \\
\text { undique }\end{array}$ & $\begin{array}{l}\text { Caeterum cum } \\
\text { vndique }\end{array}$ \\
\hline $206 ; 535$ & $\begin{array}{l}\text { Dialectica vero } \\
\text { edulium }\end{array}$ & $\begin{array}{l}\text { Dialectica uero } \\
\text { edulium }\end{array}$ & $\begin{array}{l}\text { Dialectice vero } \\
\text { edulium }\end{array}$ \\
\hline $206 ; 540$ & $\begin{array}{l}\text { in Xysto siue in } \\
\text { palaestra }\end{array}$ & $\begin{array}{l}\text { in Xysto siue in } \\
\text { palaestra }\end{array}$ & $\begin{array}{l}\text { im xysto siue in } \\
\text { palestra }\end{array}$ \\
\hline $206 ; 542-543$ & $\begin{array}{l}\text { nempe pingues et } \\
\text { saxeos }\end{array}$ & $\begin{array}{l}\text { nempe pingues et } \\
\text { saxeos }\end{array}$ & $\begin{array}{l}\text { nempe pingues ac } \\
\text { saxios }\end{array}$ \\
\hline $208 ; 578$ & delitiis & delitiis & deliciis \\
\hline
\end{tabular}




\begin{tabular}{|c|c|c|c|}
\hline $208 ; 584$ & exhulcerationibus & exhulcerationibus & exulcerationibus \\
\hline $208 ; 592$ & Graecorum & Graecorum & Grecorum \\
\hline $208 ; 594$ & dum eiectis consuetis & dum eiectis consuetis & $\begin{array}{l}\text { dum ei〈ciendis〉 } \\
\text { consuetis }\end{array}$ \\
\hline $208 ; 595$ & item aliarum rerum & item aliarum rerum & $\begin{array}{l}\text { itemque aliarum } \\
\text { rerum }\end{array}$ \\
\hline $208 ; 609$ & foetumque perdant & foetumque perdant & fetumque perdant \\
\hline $209 ; 615$ & Praestabilius & Praestabilius & Prestabilius \\
\hline $209 ; 615$ & praescripto & praescripto & prescripto \\
\hline $209 ; 617$ & praesensio & praesensio & presensio \\
\hline $209 ; 618$ & praeparatam & praeparatam & preparatam \\
\hline $209 ; 625$ & me quidem inquiebam & Ime quidem inquiebam & 1 me quidem inqui $\langle t\rangle$ \\
\hline $209 ; 626$ & otii & otii & ocii \\
\hline $209 ; 626$ & haec & haec & hec \\
\hline $209 ; 631$ & praestanda & praestanda & prestanda \\
\hline $210 ; 636-637$ & $\begin{array}{l}\text { bonam corporis } \\
\text { constitutionem }\end{array}$ & $\begin{array}{l}\text { bonam corporis } \\
\text { constitutionem }\end{array}$ & $\begin{array}{l}\text { bonam corporis } \\
\text { institutionem }\end{array}$ \\
\hline $210 ; 640$ & inquiebam & inquiebam & inqui<t \\
\hline $210 ; 641$ & praecipere & praecipere & precipere \\
\hline $210 ; 642$ & otium & otium & ocium \\
\hline $210 ; 646$ & Cum interim nihil & Cum interim nihil & Quum interim nihil \\
\hline $210 ; 656$ & negotiis & negotiis & negociis \\
\hline $210 ; 658$ & negotiis & negotiis & negociis \\
\hline $210 ; 658$ & remissus sit et otiosus & remissus sit et otiosus & $\begin{array}{l}\text { remissus sit ac } \\
\text { ociosus }\end{array}$ \\
\hline $210 ; 659$ & $\begin{array}{l}\text { praeclara et ardua } \\
\text { negotia }\end{array}$ & $\begin{array}{l}\text { praeclara et ardua } \\
\text { negotia }\end{array}$ & $\begin{array}{l}\text { preclara et ardua } \\
\text { negocia }\end{array}$ \\
\hline $210 ; 660$ & detrectans & detrectans & detractans \\
\hline $210 ; 661$ & otio & otio & ocio \\
\hline $210 ; 663$ & negotia & negotia & negocia \\
\hline $210 ; 666$ & plaerique & plaerique & plerique \\
\hline $210 ; 670-671$ & desyderet studium & desideret studium & desideret studium \\
\hline $210 ; 671$ & praecepit & praecepit & precepit \\
\hline $211 ; 677$ & delitias & delitias & delicias \\
\hline $211 ; 681-682$ & desyderant & desyderant & desiderant \\
\hline $211 ; 682$ & negotiis & negotiis & negociis \\
\hline $211 ; 686$ & otium & otium & ocium \\
\hline $211 ; 686$ & negotiis & negociis & negociis \\
\hline $211 ; 688$ & otium & otium & ocium \\
\hline $211 ; 689$ & $\begin{array}{l}\text { negotiis in otium sese } \\
\text { receperint }\end{array}$ & $\begin{array}{l}\text { negociis in otium sese } \\
\text { receperint }\end{array}$ & $\begin{array}{l}\text { negociis in ocium } \\
\text { sese receperint }\end{array}$ \\
\hline $211 ; 705$ & accipiat quam sicca & accipiat quam sicca & accipiat an sicca \\
\hline $212 ; 713$ & opsoniorum & opsoniorum & obsoniorum \\
\hline $212 ; 717$ & negotii & negotii & Negocii \\
\hline $212 ; 721$ & quod non meminerint & quod non meminerint & quod non meminerint \\
\hline $212 ; 728-729$ & $\begin{array}{l}\text { ne studiosis aut } \\
\text { rempublicam } \\
\text { administrantibus viris } \\
\text { accidat }\end{array}$ & $\begin{array}{l}\text { ne studiosis aut } \\
\text { rempublicam } \\
\text { administrantibus viris } \\
\text { accidat }\end{array}$ & $\begin{array}{l}\text { ne studiosis aut } \\
\text { rempublicam } \\
\text { administrantibus } \\
\text { accidant }\end{array}$ \\
\hline
\end{tabular}




\begin{tabular}{|c|c|c|c|}
\hline $212 ; 743$ & praemii & praemii & premii \\
\hline $212 ; 747$ & $\tau \dot{\varepsilon} \lambda \mathrm{o \sigma}$ & $\tau \dot{\varepsilon} \lambda \mathrm{o \sigma}$ & Finis \\
\hline \multicolumn{4}{|c|}{$\begin{array}{l}\text { [IV.] In principe requiri doctrinam Plutarchi commentarium, Erasmo Roterodamo } \\
\text { interprete }\end{array}$} \\
\hline $217 ; 1-3$ & $\begin{array}{l}\text { In principe requiri } \\
\text { doctrinam Plutarchi } \\
\text { commentarium, } \\
\text { Erasmo Roterodamo } \\
\text { interprete }\end{array}$ & $\begin{array}{l}\text { In principe requiri } \\
\text { doctrinam Plutarchi } \\
\text { commentarium, } \\
\text { Erasmo Roterodamo } \\
\text { interprete }\end{array}$ & $\begin{array}{l}\text { In principe requiri } \\
\text { doctrinam Plutarchi } \\
\text { commentarium, } \\
\text { Erasmo Roterodamo } \\
\text { interprete }\end{array}$ \\
\hline $217 ; 6$ & felices & foelices & foelices \\
\hline $217 ; 7$ & ac *morosam esse & ac morosum esse & ac morosum esse \\
\hline $217 ; 7$ & felicitatis & foelicitatis & foelicitatis \\
\hline $217 ; 8$ & difficile est iis & difficile est his & difficile est his \\
\hline $217 ; 11$ & qui, cum primus & qui, quum primus & qui, quum primus \\
\hline $217 ; 16$ & $\begin{array}{l}\text { Theopompus ex } \\
\text { imperio velut e } \\
\text { magno flumine } \\
\text { deductis riuis }\end{array}$ & $\begin{array}{l}\text { Theopompus ex } \\
\text { imperio uelut magno } \\
\text { flumine deductis riuis }\end{array}$ & $\begin{array}{l}\text { Thepompus ex } \\
\text { imperio velut magno } \\
\text { flumine deductis riuis }\end{array}$ \\
\hline $217 ; 27-28$ & $\begin{array}{l}\text { At ineruditi duces ac } \\
\text { principes }\end{array}$ & $\begin{array}{l}\text { At ineruditi duces ac } \\
\text { principes }\end{array}$ & $\begin{array}{l}\text { At ineruditi reges ac } \\
\text { principes }\end{array}$ \\
\hline $218 ; 32$ & $\begin{array}{l}\text { admota quatinus sibi } \\
\text { congruunt }\end{array}$ & $\begin{array}{l}\text { admota quatenus sibi } \\
\text { congruunt }\end{array}$ & $\begin{array}{l}\text { admota quatenus sibi } \\
\text { congruunt }\end{array}$ \\
\hline $218 ; 44$ & negotii & negocii & negocii \\
\hline $218 ; 45$ & atque ea cura negotia & atque ea cura negocia & atque ea cura negocia \\
\hline $218 ; 47$ & Polemon dicebat & Polemon dicebat & Polemo dicebat \\
\hline $218 ; 63$ & iustitiam tuetur & iusticiam tuetur & iusticiam tuetur \\
\hline $218 ; 69$ & $\begin{array}{l}\text { aequitatem, iustitiam, } \\
\text { veritatem }\end{array}$ & $\begin{array}{l}\text { aequitatem, iusticiam, } \\
\text { ueritatem }\end{array}$ & $\begin{array}{l}\text { aequitatem, iusticiam, } \\
\text { veritatem }\end{array}$ \\
\hline $219 ; 72$ & $\begin{array}{l}\text { Non enim felix est } \\
\text { deus vitae spatio }\end{array}$ & $\begin{array}{l}\text { Non enim foelix est } \\
\text { deus uitae spatio }\end{array}$ & $\begin{array}{l}\text { Non enim foelix est } \\
\text { deus uitae spatio }\end{array}$ \\
\hline $219 ; 75$ & Clito iustitiam & Clito iusticiam & Clito iusticiam \\
\hline $219 ; 78$ & $\begin{array}{l}\text { Ioui iustitia, sed ipse } \\
\text { iustitia fasque est }\end{array}$ & $\begin{array}{l}\text { Ioui iusticia, sed ipse } \\
\text { iusticia phasque est }\end{array}$ & $\begin{array}{l}\text { Ioui iusticia, sed ipse } \\
\text { iusticia phasque est }\end{array}$ \\
\hline $219 ; 83$ & vt ii maxime & ut hi maxime & vt hi maxime \\
\hline $219 ; 86$ & vt iis, quibus imperat & ut his, quibus imperat & vt his, quibus imperat \\
\hline $220 ; 88$ & $\begin{array}{l}\text { sed iis quae } \\
\text { custodiunt }\end{array}$ & $\begin{array}{l}\text { sed his, quae } \\
\text { custodiunt }\end{array}$ & $\begin{array}{l}\text { sed his, quae } \\
\text { custodiunt }\end{array}$ \\
\hline $220 ; 108$ & $\begin{array}{l}\text { Quemadmodum in } \\
\text { caelo }\end{array}$ & $\begin{array}{l}\text { Quemadmodum in } \\
\text { coelo }\end{array}$ & $\begin{array}{l}\text { Quemadmodum in } \\
\text { coelo }\end{array}$ \\
\hline $220 ; 109$ & $\begin{array}{l}\text { repraesentet, ostendit } \\
\text { iis }\end{array}$ & $\begin{array}{l}\text { representet, ostendit } \\
\text { his }\end{array}$ & $\begin{array}{l}\text { representet, ostendit } \\
\text { his }\end{array}$ \\
\hline $220 ; 110$ & iustitiae & iusticiae & Iusticiae \\
\hline $221 ; 138$ & $\begin{array}{l}\text { supplicia peruertunt } \\
* \text { accusatisnes }\end{array}$ & $\begin{array}{l}\text { supplicia peruertunt } \\
\text { accusationes }\end{array}$ & $\begin{array}{l}\text { supplicia praeuertunt } \\
\text { accusationes }\end{array}$ \\
\hline $221 ; 144$ & malitia & malicia & malicia \\
\hline $222 ; 153$ & $\begin{array}{l}\text { Cimoni vinum } \\
\text { obiiciebatur }\end{array}$ & $\begin{array}{l}\text { Cimoni vinum } \\
\text { obiiciebatur }\end{array}$ & $\begin{array}{l}\text { Cimoni vinum } \\
\text { obiciebatur }\end{array}$ \\
\hline
\end{tabular}


[V.] Cum principibus maxime philosophum debere disputare

\begin{tabular}{|c|c|c|c|}
\hline $225 ; 1-3$ & $\begin{array}{l}\text { Cum principibus } \\
\text { maxime philosophum } \\
\text { debere disputare } \\
\text { Plutarchi Erasmo } \\
\text { interprete }\end{array}$ & $\begin{array}{l}\text { Cum principibus } \\
\text { maxime philosophum } \\
\text { debere disputare } \\
\text { Plutarchi Erasmo } \\
\text { interprete }\end{array}$ & $\begin{array}{l}\text { Cum principibus } \\
\text { maxime philosophum } \\
\text { debere disputare } \\
\text { Plutarchi Erasmo } \\
\text { interprete }\end{array}$ \\
\hline $226 ; 18$ & $\begin{array}{l}\text { quaecumque } \\
\text { aggreditur, negotiosa } \\
\text { viuaque }\end{array}$ & $\begin{array}{l}\text { quaecumque } \\
\text { aggreditur, negotiosa } \\
\text { viuaque }\end{array}$ & $\begin{array}{l}\text { quaecumque } \\
\text { aggreditur, ac } \\
\text { negotiosa viuaque }\end{array}$ \\
\hline $226 ; 34$ & iustitia & iusticia & iusticia \\
\hline $226 ; 35$ & $\begin{array}{l}\text { qui cum eis habent } \\
\text { commercium }\end{array}$ & $\begin{array}{l}\text { qui cum eis habent } \\
\text { commercium }\end{array}$ & $\begin{array}{l}\text { qui cum iis habent } \\
\text { commercium }\end{array}$ \\
\hline $226 ; 36$ & haerbam & herbam & herbam \\
\hline $226 ; 37-38$ & haerbam & herbam & herbam \\
\hline $226 ; 46$ & At Catho & Ac Catho & Ac Catho \\
\hline $226 ; 52$ & Pauli Aemylii & Pauli Aemylii & Pauli Aemilii \\
\hline $228 ; 72$ & $\begin{array}{l}\text { Mercurium } \\
\text { negotiatorem }\end{array}$ & $\begin{array}{l}\text { Mercurium } \\
\text { negociatorem }\end{array}$ & $\begin{array}{l}\text { Mercurium } \\
\text { negociatorem }\end{array}$ \\
\hline $228 ; 75$ & Clio gaudere iis & Clio gaudere his & Clio gaudere his \\
\hline $228 ; 84$ & gloriae desyderabit & gloriae desiderabit & gloriae desiderabit \\
\hline $228 ; 84$ & $\begin{array}{l}\text { quantum satis est ad } \\
\text { conciliandum illi in } \\
\text { rebus gerendi } \\
\text { authoritatem }\end{array}$ & $\begin{array}{l}\text { quantum satis est ad } \\
\text { conciliandum illi in } \\
\text { rebus gerendi } \\
\text { authoritatem }\end{array}$ & $\begin{array}{l}\text { quantum satis est ad } \\
\text { conciliandam illi in } \\
\text { rebus gerendi } \\
\text { authoritatem }\end{array}$ \\
\hline $228 ; 85$ & $\begin{array}{l}\text { quae nascitur inde } \\
\text { quod vir optimus } \\
\text { creditur }\end{array}$ & $\begin{array}{l}\text { quae nascitur inde } \\
\text { quod uir optimus } \\
\text { creditur }\end{array}$ & $\begin{array}{l}\text { quae nascitur ex eo, } \\
\text { quod illi creditur }\end{array}$ \\
\hline $228 ; 86$ & $\begin{array}{l}\text { neque facile prodesse } \\
\text { siquis nolit prodesse }\end{array}$ & $\begin{array}{l}\text { neque facile prodesse } \\
\text { siquis nolit prodesse }\end{array}$ & $\begin{array}{l}\text { neque facile prodesse } \\
\text { iis, qui nolint alium } \\
\text { sibi prodesse }\end{array}$ \\
\hline $228 ; 88$ & quam iis qui vident & quam his, qui uident & quiam his, qui vident \\
\hline $228 ; 88-89$ & $\begin{array}{l}\text { potius quam iis, qui } \\
\text { non negligunt }\end{array}$ & $\begin{array}{l}\text { potius quam his, qui } \\
\text { non negliguntur }\end{array}$ & $\begin{array}{l}\text { potius quam his, qui } \\
\text { non negliguntur }\end{array}$ \\
\hline $228 ; 89$ & publicis negotiis & publicis negociis & publicis negociis \\
\hline $228 ; 93-94$ & $\begin{array}{l}\text { potentiam regiam nec } \\
\text { oportet }\end{array}$ & $\begin{array}{l}\text { potentiam regiam nec } \\
\text { oportet }\end{array}$ & $\begin{array}{l}\text { potentiam regiam non } \\
\text { oportet }\end{array}$ \\
\hline $228 ; 97$ & adest decor et forma & adest decor et forma & adest decor ac forma \\
\hline $228 ; 106$ & $\begin{array}{l}\text { Verum cum iis, qui } \\
\text { cupiunt }\end{array}$ & $\begin{array}{l}\text { Verum cum his, qui } \\
\text { cupiunt }\end{array}$ & $\begin{array}{l}\text { Verum cum his, qui } \\
\text { cupiunt }\end{array}$ \\
\hline $230 ; 118$ & Ageliae & Ageliae & Aglaiae \\
\hline $230 ; 128-129$ & execrabiles & execrabiles & exsecrabiles \\
\hline $230 ; 130$ & sic ii & sic hi & sic hi \\
\hline $230 ; 148-149$ & $\begin{array}{l}\text { Quisquis hunc } \\
\text { instituendum } \\
\text { acceperit vir ciuilis et } \\
\text { aptus principibus }\end{array}$ & $\begin{array}{l}\text { Quisquis hunc } \\
\text { instituendum } \\
\text { acceperit vir ciuilis et } \\
\text { aptus principibus }\end{array}$ & $\begin{array}{l}\text { Quisquis hunc } \\
\text { instituendum } \\
\text { acceperit vis ciuilis et } \\
\text { aptus principibus }\end{array}$ \\
\hline \multirow{2}{*}{$\frac{\text { [VI.] } U t}{235 ; 17}$} & & & \\
\hline & $\begin{array}{l}\text { pelle cum pardo } \\
\text { certaret }\end{array}$ & $\begin{array}{l}\text { pelle cum pardali } \\
\text { certaret }\end{array}$ & $\begin{array}{l}\text { pelle cum pardali } \\
\text { certaret }\end{array}$ \\
\hline
\end{tabular}




\begin{tabular}{|c|c|c|c|}
\hline $235 ; 19$ & illa contra flauor & illi contra flauor & illi contra flauor \\
\hline $235 ; 20$ & $\begin{array}{l}\text { videbis me pardo } \\
\text { magis uersicolorem }\end{array}$ & $\begin{array}{l}\text { uidebis me pardali } \\
\text { magis uersicolorem }\end{array}$ & $\begin{array}{l}\text { videbis me pardali } \\
\text { magis versicolorem }\end{array}$ \\
\hline $235 ; 22$ & \multicolumn{3}{|c|}{$\begin{array}{l}\begin{array}{l}\text { compluries quidem. Ocompluries quidem. Ocompluries quidem, } \\
\text { homo morbos }\end{array} \\
\text { homo morbos }\end{array} \begin{array}{l}\text { homo, morbos } \\
\text { homo }\end{array}$} \\
\hline $236 ; 31$ & ratio sana praecipit & ratio sana praecipit & ratio sana percipit \\
\hline $236 ; 32$ & at in animi morbos & at in animi morbos & at in animi morb $\langle i\rangle \mathrm{s}$ \\
\hline $236 ; 39$ & perniciosores sunt ii & pernitiosores sunt hi & pernitiosores sunt hi \\
\hline $236 ; 40$ & lathargus & lethargus & lethargus \\
\hline \multirow[t]{2}{*}{$238 ; 86$} & Ascreo Ioui Lydorum & Ascreo Ioui Lydorum & $\begin{array}{l}\text { Ascraeo Ioui } \\
\text { Lydorum }\end{array}$ \\
\hline & 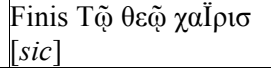 & 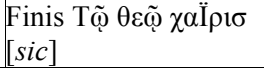 & - \\
\hline \multicolumn{4}{|c|}{ 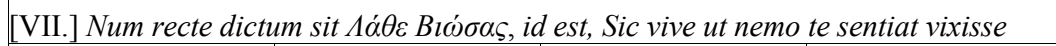 } \\
\hline $241 ; 1-2$ & 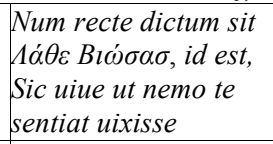 & 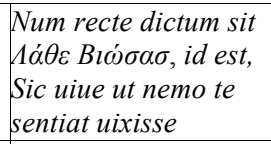 & 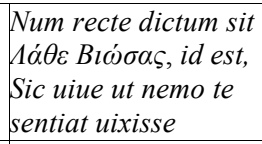 \\
\hline $241 ; 7$ & dosonatores nobiles & obsonatores nobiles & obsonatores nobiles \\
\hline $241 ; 13-14$ & gloriam velut auersi & gloriam uelut auersi & gloriam veluti auersi \\
\hline $242 ; 23$ & Abi, coniice & Abi, coniice & Abi, conice \\
\hline $242 ; 26$ & $\begin{array}{l}\text { ceu pulsum quendam } \\
\text { exhibire iis }\end{array}$ & $\begin{array}{l}\text { ceu pulsum quendam } \\
\text { exhibire his }\end{array}$ & $\begin{array}{l}\text { ceu pulsum quendam } \\
\text { exhibire his }\end{array}$ \\
\hline $242 ; 33$ & $\begin{array}{l}\text { Hunc contra negant, } \\
\text { occultant }\end{array}$ & $\begin{array}{l}\text { Hunc contra negant, } \\
\text { occultant }\end{array}$ & $\begin{array}{l}\text { Nunc contra negant, } \\
\text { occultant }\end{array}$ \\
\hline $242 ; 44$ & ocium arti & otium arti & otium arti \\
\hline $243 ; 63$ & $\begin{array}{l}\text { Refulgescit enim cum } \\
\text { res }\end{array}$ & $\begin{array}{l}\text { Refulgescit enim } \\
\text { quum res }\end{array}$ & $\begin{array}{l}\text { Refulgescit enim } \\
\text { quum res }\end{array}$ \\
\hline $244 ; 69$ & putescunt & putescunt & putrescunt \\
\hline $244 ; 69-70$ & qui in ocio degunt & qui in otio degunt & qui in otio degunt \\
\hline $244 ; 78$ & nouo in die versantes & nouo in die uersantes & $\begin{array}{l}\text { nouo in die versantes } \\
\text { hhomines〉 }\end{array}$ \\
\hline $244 ; 98$ & $\begin{array}{l}\text { quod tenebrae illi } \\
\text { suspectae terrorem } \\
\text { incutiant }\end{array}$ & $\begin{array}{l}\text { quod tenebrae illi } \\
\text { suspectae terrorem } \\
\text { incutiant }\end{array}$ & $\begin{array}{l}\text { quod tenebrae illi } \\
\text { suspectae terrorem } \\
\text { incutiunt }\end{array}$ \\
\hline $246 ; 112$ & $\begin{array}{l}\text { barathrum quoddam } \\
\text { praecipitantes }\end{array}$ & $\begin{array}{l}\text { barathrum quoddam } \\
\text { praecipitantes }\end{array}$ & $\begin{array}{l}\text { barathrum quoddam } \\
\text { praecipitans }\end{array}$ \\
\hline \multicolumn{4}{|c|}{ [VIII.] De cupiditate divitiarum } \\
\hline $251 ; 1-3$ & $\begin{array}{l}\text { Plutarchus, De } \\
\text { cupiditate diuitiarum } \\
\text { Desiderio Erasmo } \\
\text { Roterodamo } \\
\text { interprete }\end{array}$ & $\begin{array}{l}\text { Plutarchus, De } \\
\text { cupiditate diuitiarum } \\
\text { Desiderio Erasmo } \\
\text { Roterodamo } \\
\text { interprete } \\
\end{array}$ & $\begin{array}{l}\text { Plutarchi Chaeronei } \\
\text { De cupiditate } \\
\text { diuitiarum Desiderio } \\
\text { Erasmo Roterodamo } \\
\text { interprete }\end{array}$ \\
\hline $251 ; 4$ & Ippomachus & Ippomachus & Hippomachus \\
\hline $251 ; 8$ & felicitatem & felicitatem & foelicitatem \\
\hline $251 ; 9$ & felicitas & felicitas & foelicitas \\
\hline $251 ; 10$ & felicitatem & felicitatem & foelicitatem \\
\hline $251 ; 16$ & Cum potus sedat sitim & $\begin{array}{l}\text { Quum potus sedat } \\
\text { sitim }\end{array}$ & $\begin{array}{l}\text { Quum potus sed }\langle e\rangle t \\
\text { sitim }\end{array}$ \\
\hline
\end{tabular}

Humanistica Lovaniensia 68.2 (2019), 257-296 


\begin{tabular}{|c|c|c|c|}
\hline $251 ; 18$ & offenditur ac disiicit & offenditur ac disiicit & offenditur ac disicit \\
\hline $251 ; 21$ & $\begin{array}{l}\text { Nam illae cum } \\
\text { susceperint }\end{array}$ & $\begin{array}{l}\text { Nam illae quum } \\
\text { susceperint }\end{array}$ & $\begin{array}{l}\text { Nam illae quum } \\
\text { susceperint }\end{array}$ \\
\hline $251 ; 22$ & et obsonio quolibet & et opsonio quolibet & et opsonio quolibet \\
\hline $252 ; 30$ & quemadmodum ii & quemadmodum hi & quemadmodum hi \\
\hline $252 ; 30-32$ & $\begin{array}{l}\text { non sitientes }< \\
\text { atque esurientes } \\
\text { sumpserant }\end{array}$ & $\begin{array}{l}>\text { non sitientes }< \\
\text { atque esurientes } \\
\text { sumpserant }\end{array}$ & $\begin{array}{l}>\text { non sitientes }\langle\text { bibunt } \\
\text { neque esurientes } \\
\text { edunt, etiam ea, quae } \\
\text { sitientes atque } \\
\text { esurientes sumpserant } \\
\text { [both editions skip } \\
\text { from the first to the } \\
\text { second esurientes]. }\end{array}$ \\
\hline $252 ; 32$ & sic ii, dum & sic hi, dum & sic hi, dum \\
\hline $252 ; 36-37$ & $\begin{array}{l}\text { multumque biberit } \\
\text { expletus, adit medicos } \\
\text { percontatus }\end{array}$ & $\begin{array}{l}\text { multumque biberit } \\
\text { sec unquam } \\
\text { expleatur, adit } \\
\text { medicos percontatus }\end{array}$ & $\begin{array}{l}\text { multumque biberit } \\
\text { nec vnquam } \\
\text { expleatur, adit } \\
\text { medicos percontatus }\end{array}$ \\
\hline $252 ; 39$ & totidem quo emat & totidem coemat & totidem coemat \\
\hline $252 ; 40$ & non tamen explet & non tamen expletur & non tamen expletur \\
\hline \multirow[t]{3}{*}{$252 ; 42-43$} & $\begin{array}{l}\text { qui, cum nondum } \\
\text { biberit }\end{array}$ & $\begin{array}{l}\text { qui, quum nondum } \\
\text { biberit }\end{array}$ & $\begin{array}{l}\text { qui, quum nondum } \\
\text { biberit }\end{array}$ \\
\hline & aut amici cuiuspiam & aut amici cuiuspiam & aut amici cuiuspiam \\
\hline & $\begin{array}{l}\text { ope }\langle\quad>\text { liberatus a } \\
\text { foeneratore. Ast qui } \\
\text { plura }\end{array}$ & $\begin{array}{l}\text { aope }\langle\quad>\text { liberatus } \\
\text { foeneratore. Ast qui } \\
\text { plura }\end{array}$ & $\begin{array}{l}\text { aope persoluto aere } \\
\text { alieno liberatus a } \\
\text { foeneratore. Ast qui } \\
\text { plura }\end{array}$ \\
\hline $252 ; 51-52$ & $\begin{array}{l}\text { Neque tamen huius } \\
\text { morbus }\end{array}$ & $\begin{array}{l}\text { Neque tamen huius } \\
\text { morbus }\end{array}$ & $\begin{array}{l}\text { Neque enim huius } \\
\text { morbus }\end{array}$ \\
\hline $252 ; 53-54$ & $\begin{array}{l}\text { seu malum } \\
\text { transuersim }\end{array}$ & $\begin{array}{l}\text { seu malum } \\
\text { transuersim }\end{array}$ & $\begin{array}{l}\text { ceu malum } \\
\text { transuersim }\end{array}$ \\
\hline $252 ; 58-59$ & $\begin{array}{l}\text { Nos igitur, cum } \\
\text { viderimus hominem }\end{array}$ & $\begin{array}{l}\text { Nos igitur, quum } \\
\text { uiderimus hominem }\end{array}$ & $\begin{array}{l}\text { Nos igitur, quum } \\
\text { viderimus hominem }\end{array}$ \\
\hline $252 ; 59-60$ & A nulla turpidine & A nulla turpitudine & A nulla turpitudine \\
\hline $252 ; 61$ & $\begin{array}{l}\text { Cum domos habeat, } \\
\text { agros, armenta }\end{array}$ & $\begin{array}{l}\text { quum domos habeat, } \\
\text { agros, armenta }\end{array}$ & $\begin{array}{l}\text { quum domos habeat, } \\
\text { agros, armenta }\end{array}$ \\
\hline $252 ; 67$ & $\begin{array}{l}\text { Alioqui }\langle>\text {, qui } \\
\text { sapiunt, ii naturae } \\
\text { modum }\end{array}$ & $\begin{array}{l}\text { Alioqui hi, qui } \\
\text { sapiunt, hi naturae } \\
\text { modum }\end{array}$ & $\begin{array}{l}\text { Alioqui hi, qui } \\
\text { sapiunt, hi naturae } \\
\text { modum }\end{array}$ \\
\hline $252-253 ; 67-68$ & $\begin{array}{l}\text { habent praescriptum } \\
\text { adestque finis }< \\
\text { veluti stimulo et } \\
\text { interstitio } \\
\text { circunscriptus }\end{array}$ & $\left.\begin{array}{l}\text { habent praescriptum } \\
\text { adestque finis }< \\
\text { veluti stimulo et } \\
\text { interstitio } \\
\text { circunscriptus }\end{array}\right\rangle$ & $\begin{array}{l}\text { habent praescriptum } \\
\text { adestque finis aliquis } \\
\text { vsus veluti stimulo et } \\
\text { interstitio } \\
\text { circumscriptus }\end{array}$ \\
\hline $253 ; 75$ & $\begin{array}{l}\text { Sed iidem in malis } \\
\text { sunt in quibus } \\
\text { Thrasonides ille }\end{array}$ & $\begin{array}{l}\text { Sed iisdem in malis } \\
\text { sunt, in quibus } \\
\text { Thrasonides ille }\end{array}$ & $\begin{array}{l}\text { Sed iisdem in malis } \\
\text { 〈est>, in quibus } \\
\text { Thrasonides ille }\end{array}$ \\
\hline $253 ; 76$ & $\begin{array}{l}\text { Quemadmodum } \\
\text { solent ii, qui } \\
\text { insanissime amant }\end{array}$ & $\begin{array}{l}\text { Quemadmodum } \\
\text { solent hi, qui } \\
\text { insanissime amant }\end{array}$ & $\begin{array}{l}\text { quemadmodum solent } \\
\text { hi, qui insanissime } \\
\text { amant }\end{array}$ \\
\hline $253 ; 77$ & negociatoribus & negociatoribus & negotiatoribus \\
\hline
\end{tabular}




\begin{tabular}{|c|c|c|c|}
\hline $253 ; 80$ & $\begin{array}{l}\text { Sophocles } \\
\text { interrogatus, possetne } \\
\text { ingredi cum muliere }\end{array}$ & $\begin{array}{l}\text { Sophocles } \\
\text { interrogatus, possetne } \\
\text { ingredi cum muliere }\end{array}$ & $\begin{array}{l}\text { Sophocles } \\
\text { interrogatus, possetne } \\
\text { congredi cum muliere }\end{array}$ \\
\hline $253 ; 81$ & $\begin{array}{l}\text { ab inclaementibus } \\
\text { istis }\end{array}$ & $\begin{array}{l}\text { ab inclaementibus } \\
\text { istis }\end{array}$ & ab inclementibus istis \\
\hline $254 ; 87$ & $\begin{array}{l}\text { luxuriem taxauit, cum } \\
\text { diceret }\end{array}$ & $\begin{array}{l}\text { luxuriem taxauit, } \\
\text { quum diceret }\end{array}$ & $\begin{array}{l}\text { luxuriem taxauit, } \\
\text { quum diceret }\end{array}$ \\
\hline $254 ; 89-90$ & $\begin{array}{l}\text { tanquam splendidi, } \\
\text { vtuntur autem } \\
\text { tanquam sordidi et } \\
\text { labores tolerant, cum } \\
\text { careant voluptatibus }\end{array}$ & $\begin{array}{l}\text { tanquam splendidi, } \\
\text { utuntur autem sordidi, } \\
\text { et labores tolerant, } \\
\text { quum careant } \\
\text { uoluptatibus }\end{array}$ & $\begin{array}{l}\text { tanquam splendidi, } \\
\text { vtuntur autem velut } \\
\text { sordidi et labores } \\
\text { tolerant, quum careant } \\
\text { voluptatibus }\end{array}$ \\
\hline \multirow[t]{2}{*}{$254 ; 90$} & Itaque cum Demades & $\begin{array}{l}\text { Itaque quum } \\
\text { Demades }\end{array}$ & $\begin{array}{l}\text { Itaque quum } \\
\text { Demades }\end{array}$ \\
\hline & $\begin{array}{l}\text { Demiror te, Phocion } \\
\text { inquit, qui } \\
\text { rempublicam } \\
\text { administres, cum } \\
\text { possis ad istum } \\
\text { prandere modum }\end{array}$ & $\begin{array}{l}\text { Demiror te, Phocion } \\
\text { inquit, qui } \\
\text { rempublicam } \\
\text { administres, quum } \\
\text { possis ad istum } \\
\text { prandere modum }\end{array}$ & $\begin{array}{l}\text { Demiror te, }\langle\rangle \text { inquit, } \\
\text { qui rempublicam } \\
\text { administres, quum } \\
\text { possis ad istum } \\
\text { prandere modum }\end{array}$ \\
\hline $254 ; 96-97$ & $\begin{array}{l}\text { infelicissime, si cum } \\
\text { possis }\end{array}$ & $\begin{array}{l}\text { infoelicissime, si } \\
\text { quum possis }\end{array}$ & $\begin{array}{l}\text { infoelicissime, si } \\
\text { quum possis }\end{array}$ \\
\hline $254 ; 97$ & ad modum \langle\rangle vitam & $\begin{array}{l}\text { ad modum uiuere } \\
\text { uitam }\end{array}$ & $\begin{array}{l}\text { ad modum viuere } \\
\text { vitam }\end{array}$ \\
\hline $254 ; 98$ & $\begin{array}{l}\text { nemini quicquam } \\
\text { impartiens, tam } \\
\text { incomis in amico }\end{array}$ & $\begin{array}{l}\text { nemini quicquam } \\
\text { impertiens, tam } \\
\text { incomis in amicos }\end{array}$ & $\begin{array}{l}\text { nemini quicquam } \\
\text { impertiens, tam } \\
\text { incomis in amicos }\end{array}$ \\
\hline $254 ; 100$ & $\begin{array}{l}\text { submittis te, cum } \\
\text { tantum }\end{array}$ & $\begin{array}{l}\text { submittis te, quum } \\
\text { tantum }\end{array}$ & $\begin{array}{l}\text { submittis te, quum } \\
\text { tantum }\end{array}$ \\
\hline $254 ; 101$ & $\begin{array}{l}\text { Narrant Bizantium } \\
\text { quendam, cum } \\
\text { moechum }\end{array}$ & $\begin{array}{l}\text { Narrant Biçantium } \\
\text { quendam, quum } \\
\text { moechum }\end{array}$ & $\begin{array}{l}\text { Narrant Byzantium } \\
\text { quendam, quum } \\
\text { moechum }\end{array}$ \\
\hline $254 ; 106-108$ & $\begin{array}{l}\text { satellitium alunt, } \\
\text { munera mittunt, alunt } \\
\text { exercitus, sociorum } \\
\text { auxilia redimunt. Tu } \\
\text { vero tantum negotii } \\
\text { sustines, perturbans } \\
\text { ac distorquens te } \\
\text { ipsum }\end{array}$ & $\begin{array}{l}\text { satellitium alunt, } \\
\text { munera mittunt, alunt } \\
\text { exercitus, sociorum } \\
\text { auxilla redimunt. Tu } \\
\text { uero tantum negocii } \\
\text { sustines, perturbans, } \\
\text { ac distorquens te } \\
\text { ipsum }\end{array}$ & $\begin{array}{l}\text { satellitium alunt, } \\
\text { munera mittunt, alunt } \\
\text { exercitus, dum, qui } \\
\text { singulari certamine } \\
\text { congrediuntur, } \\
\text { ke>munt. Tu vero } \\
\text { tantum negocii } \\
\text { sustines perturbans et } \\
\text { distorquens te ipsum }\end{array}$ \\
\hline $254 ; 110$ & $\begin{array}{l}\text { qui cum ligna } \\
\text { sarmentaque deportet }\end{array}$ & $\begin{array}{l}\text { qui quum ligna } \\
\text { sarmentque deportet }\end{array}$ & $\begin{array}{l}\text { qui quum ligna } \\
\text { sarmentaque deportet }\end{array}$ \\
\hline $254 ; 113$ & $\begin{array}{l}\text { Atque haec dixerim, } \\
\text { aduersus insanam } \\
\text { istam ac formicarum } \\
\text { vitae }\end{array}$ & $\begin{array}{l}\text { Atque haec dixerim, } \\
\text { aduersus insanam } \\
\text { istam ac formicarum } \\
\text { uitae }\end{array}$ & $\begin{array}{l}\text { Atque haec dixerim } \\
\text { aduersus asiniam } \\
\text { istam ac formicarum } \\
\text { vitae }\end{array}$ \\
\hline $254 ; 116$ & pluribus negotiis & pluribus negociis & pluribus negociis \\
\hline $254 ; 117$ & $\begin{array}{l}\text { Atque haec omnia } \\
\text { cum faciat }\end{array}$ & $\begin{array}{l}\text { Atque haec omnia } \\
\text { quum faciat }\end{array}$ & $\begin{array}{l}\text { Atque haec omnia } \\
\text { quum faciat }\end{array}$ \\
\hline
\end{tabular}




\begin{tabular}{|c|c|c|c|}
\hline $254 ; 120$ & capientes ex iis & capientes ex his & capientes ex his \\
\hline $254 ; 121$ & infensos esse iis & infensos esse his & infensos esse his \\
\hline $254 ; 123$ & cum abundant et & quum abundant et & quum abundant et \\
\hline $255 ; 125$ & Demosthenes iis & Demosthenes his & Demosthenes his \\
\hline $255 ; 131$ & nihil impartiunt & nihil impertiunt & nihil impertiunt \\
\hline $255 ; 134$ & ut ii quoque & ut hi quoque & vt hi quoque \\
\hline $255 ; 138$ & $\begin{array}{l}\text { comminuto alio } \\
\text { diuitias auertat }\langle\rangle \text { aut } \\
\text { donet }\end{array}$ & $\begin{array}{l}\text { comminuto alio } \\
\text { diuitias auertat ac } \\
\text { deriuet aut donec }\end{array}$ & $\begin{array}{l}\text { comminuto alio } \\
\text { diuitias auertat ac } \\
\text { deriuet aut donec }\end{array}$ \\
\hline $255 ; 140$ & $\begin{array}{l}\text { Non tamen seruorum } \\
\text { tantum liberi } \\
\text { nascuntur lasciui, } \\
\text { verum etiam } \\
\text { sordidorum }\end{array}$ & $\begin{array}{l}\text { Non enim seruorum } \\
\text { tantum liberi } \\
\text { nascuntur lasciui, } \\
\text { uerum etiam } \\
\text { sordidorum }\end{array}$ & $\begin{array}{l}\text { Non enim seruorum } \\
\text { tantum liberi, iuxta } \\
\text { Euripidis sententiam, } \\
\text { verum etiam } \\
\text { sordidorum }\end{array}$ \\
\hline $256 ; 147$ & $\begin{array}{l}\text { Atqui istud non est } \\
\text { instituere }\end{array}$ & $\begin{array}{l}\text { Atque [atqui?] istud } \\
\text { non est instituere }\end{array}$ & $\begin{array}{l}\text { Atque istud non est } \\
\text { instituere }\end{array}$ \\
\hline $256 ; 150$ & Ac auarorum liberi & At auarorum liberi & At auarorum liberi \\
\hline $256 ; 155$ & non sinant eos viuere & non sinunt eos uiuere & non sinunt eos viuere \\
\hline $256 ; 157-158$ & $\begin{array}{l}\text { et tamquam de alieno } \\
\text { impartiunt amicis }\end{array}$ & $\begin{array}{l}\text { et tanquam de alieno } \\
\text { impertiunt amicis }\end{array}$ & $\begin{array}{l}\text { et tanquam de alieno } \\
\text { impertiunt amicis }\end{array}$ \\
\hline $256 ; 160$ & vitae spes & uitae species & vitae species \\
\hline $256 ; 160$ & $\begin{array}{l}\text { austerus atque } \\
\text { ineffabilis }\end{array}$ & $\begin{array}{l}\text { austerus atque } \\
\text { ineffabilis }\end{array}$ & $\begin{array}{l}\text { austerus atque } \\
\text { inaffabilis }\end{array}$ \\
\hline $256 ; 167-168$ & libertatem et otium? & libertatem et ocium? & libertatem et ocium? \\
\hline $256 ; 170$ & $\begin{array}{l}\text { tanquam praeproperas } \\
\text { rugas et canas } \\
\text { inducens animo }\end{array}$ & $\begin{array}{l}\text { tanquam praeproperas } \\
\text { rugas et canas } \\
\text { inducens animo }\end{array}$ & $\begin{array}{l}\text { tanquam praeproperas } \\
\text { rugas et canos } \\
\text { inducens animo }\end{array}$ \\
\hline $256 ; 171$ & negotiis & negociis & negociis \\
\hline $256 ; 171-172$ & $\begin{array}{l}\text { per quae marcessit } \\
\text { marcescit alacritas }\end{array}$ & $\begin{array}{l}\text { per quae marcescit } \\
\text { alacritas }\end{array}$ & $\begin{array}{l}\text { per quae marcescit } \\
\text { alacritas }\end{array}$ \\
\hline $256 ; 184$ & $\begin{array}{l}\text { ita stragulas purpuras, } \\
\text { mensas purpuras } \\
\text { preciosas }\end{array}$ & $\begin{array}{l}\text { ita stragulas purpuras, } \\
\text { mensas preciosas }\end{array}$ & $\begin{array}{l}\text { ita stragulas } \\
\text { purpureas, mensas } \\
\text { preciosas }\end{array}$ \\
\hline $257 ; 188$ & Interea atque & Intereatque & Intereatque \\
\hline $257 ; 190$ & eiiciatur & eiiciatur & eiciatur \\
\hline $257-258 ; 193-194$ & $\begin{array}{l}\text { Imo his, inquit, felices } \\
\text { sumus ac beati }\end{array}$ & $\begin{array}{l}\text { SImo his, inquit, } \\
\text { foelices sumus ac } \\
\text { beati }\end{array}$ & $\begin{array}{l}\text { Imo his, inquit, } \\
\text { superuacaneis foelices } \\
\text { sumus ac beati }\end{array}$ \\
\hline $258 ; 204$ & habundantem & abundantem & abundantem \\
\hline $258 ; 209-211$ & $\begin{array}{l}\text { Cum debueris } \\
\text { submouere purpuram } \\
\langle\rangle \text { vt illa desineret } \\
\text { delitiarum iterumque } \\
\text { peregrinarum amore } \\
\text { laborare }\end{array}$ & $\begin{array}{l}\text { Quum debueris } \\
\text { submouere purpuram } \\
\text { <> ut illa desineret } \\
\text { delitiarum rerumque } \\
\text { peregrinarum amore } \\
\text { laborare }\end{array}$ & $\begin{array}{l}\text { Quum debueris } \\
\text { submouere purpuram } \\
\text { ac cultum, vt illa } \\
\text { desineret delitiarum } \\
\text { rerumque } \\
\text { peregrinarum amore } \\
\text { laborare }\end{array}$ \\
\hline $258 ; 213$ & felicitatem & foelicitatem & foelicitatem \\
\hline \multirow[t]{2}{*}{$258 ; 215$} & $\begin{array}{l}\text { quae scitu sunt scitu } \\
\text { necessaria }\end{array}$ & $\begin{array}{l}\text { quae scitu sunt } \\
\text { necessaria }\end{array}$ & $\begin{array}{l}\text { quae scitu sunt } \\
\text { necessaria }\end{array}$ \\
\hline & $\begin{array}{l}\text { Si nemo videat nec } \\
\text { aspiciat verae cerae }\end{array}$ & $\begin{array}{l}\text { Si nemo uideat, nec } \\
\text { aspiciat uerae caecae }\end{array}$ & $\begin{array}{l}\text { Si nemo videat nec } \\
\text { aspiciat, ver〈e }\rangle \text { caecae }\end{array}$ \\
\hline
\end{tabular}




\begin{tabular}{|l|l|l|l|}
\hline & $\begin{array}{l}\text { sunt et orbae luce suntsunt, et orbae luce } \\
\text { diuitiae }\end{array}$ & $\begin{array}{l}\text { sunt et orbae luce sunt } \\
\text { siuitiae }\end{array}$ \\
\hline $258 ; 221$ & $\begin{array}{l}\text { Siquidem diues, cum diuitiae } \\
\text { solus coenat }\end{array}$ & $\begin{array}{l}\text { Siquidem diues, quumSiquidem diues, quum } \\
\text { solus coenat }\end{array}$ & $\begin{array}{l}\text { Siquid coenat } \\
\text { solus }\end{array}$ \\
\hline $258 ; 222$ & $\begin{array}{l}\text { negotium mensis } \\
\text { conuiualibus }\end{array}$ & $\begin{array}{l}\text { negocium mensis } \\
\text { conuiualibus }\end{array}$ & $\begin{array}{l}\text { negocium mensis } \\
\text { conuiualibus }\end{array}$ \\
\hline $258 ; 223$ & plebeis & plaebeis & plaebeis \\
\hline $258 ; 225$ & lebetesque tripodes & lebetesque tripodes & lebetesque tripodas \\
\hline
\end{tabular}




\section{Appendix 3. A full list of the marginalia in OPAsc and OPFrob}

\begin{tabular}{|c|c|c|}
\hline $\begin{array}{l}\text { ASD } 4.2 \\
\text { (page; line) }\end{array}$ & OPAsc & $\begin{array}{l}\text { OPFrob } \\
\text { ('A' in } A S D 4.2)\end{array}$ \\
\hline \multicolumn{3}{|c|}{$\begin{array}{l}\text { [III.] De tuenda bona valetudine praecepta Erasmo interprete. Tà } \pi \rho o ́ \sigma \omega \pi \alpha . \\
\text { Moschion et Xeusippus }\end{array}$} \\
\hline $189 ; 8-9$ & & Ansam praebere/ Homerus \\
\hline $190 ; 18$ & & Prouerbium \\
\hline $190 ; 27$ & Carmen Homericum & Homeri uersus prouerbialis \\
\hline $190 ; 30$ & & Laus medicinae \\
\hline $190 ; 53-54$ & & $\begin{array}{l}\text { De cibis aegrotantibus } \\
\text { exhibendis }\end{array}$ \\
\hline $191 ; 68-69$ & & Aureum praeceptum \\
\hline $192 ; 78$ & & $\begin{array}{l}\text { Titus balueo [i.e., balneo] } \\
\text { etinctus }\end{array}$ \\
\hline $192 ; 90$ & & Adagium \\
\hline $192 ; 92$ & & Festiuus Philippi iocus \\
\hline $193 ; 128$ & & Socrates \\
\hline $194 ; 154$ & & Phrynes dicterium \\
\hline $194 ; 158$ & & $\begin{array}{l}\text { Plato. Voluptates ab animo in } \\
\text { corpus scatentes } \\
\text { pernitiosissimae }\end{array}$ \\
\hline $194 ; 170$ & & Simonides \\
\hline $194 ; 176$ & & Apophthegma \\
\hline $194 ; 179$ & & $\begin{array}{l}\text { Attende sordidorum naturam. } \\
\text { Adagium }\end{array}$ \\
\hline $195 ; 183$ & & Cratetis prouerbialis sententia \\
\hline $195 ; 195$ & & Arcesilai scomma \\
\hline $196 ; 217$ & & Prodicus \\
\hline $196 ; 218-219$ & & $\begin{array}{l}\text { Bona ualetudo bonum } \\
\text { diuinum }\end{array}$ \\
\hline $196 ; 223$ & & 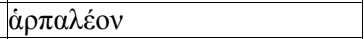 \\
\hline $196 ; 225$ & & Demades \\
\hline $196 ; 232$ & & $\begin{array}{l}\text { Lisimachus ob sitim hostibus } \\
\text { se dedidit }\end{array}$ \\
\hline $197 ; 249$ & & musica coenula \\
\hline $197 ; 250$ & & Timothei dictum \\
\hline $197 ; 251$ & & Lepidum Alexandri dictum \\
\hline $197 ; 258-259$ & & $\begin{array}{l}\text { Humorum abundantia corpus } \\
\text { ad morbos propensum reddit }\end{array}$ \\
\hline $198 ; 267$ & & Prouerbium \\
\hline $198 ; 270$ & & Hesiodus \\
\hline $198 ; 273$ & & Hipocrates \\
\hline $198 ; 287$ & & Catho \\
\hline $199 ; 308-309$ & & Laconum mos \\
\hline $199 ; 325$ & & Exacta uitae ratio inutilis \\
\hline $200 ; 334$ & & Indicia febris futurae \\
\hline $200 ; 339$ & & Democritus \\
\hline
\end{tabular}




\begin{tabular}{|c|c|}
\hline $200 ; 346$ & $\begin{array}{l}\text { Somnus et insomnia } \\
\text { consyderanda }\end{array}$ \\
\hline $200 ; 349-350$ & De affectibus animi \\
\hline $200 ; 365$ & Platonis dictum \\
\hline $201 ; 380$ & Memorabile dictum \\
\hline $202 ; 387$ & Studiosorum exercitatio \\
\hline $202 ; 395$ & $\begin{array}{l}\text { Attende commoda exercitii } \\
\text { uocis }\end{array}$ \\
\hline $202 ; 401$ & Lectionis exercitatio \\
\hline $202 ; 422$ & Socrates \\
\hline $202 ; 425$ & $\begin{array}{l}\text { Repletis et lassatis non } \\
\text { conuenit forte exercitium }\end{array}$ \\
\hline $203 ; 437$ & Non utendum frigidis balneis \\
\hline $204 ; 458$ & Aluus auribus caret \\
\hline $204 ; 460$ & Cibi multi nutrimenti \\
\hline $204 ; 462$ & Leuibus cibis immorandum \\
\hline $204 ; 465$ & $\begin{array}{l}\text { Carnium eius temperandus } \\
\text { est }\end{array}$ \\
\hline $204 ; 472$ & $\begin{array}{l}\text { Consuetudo in naturam } \\
\text { transit }\end{array}$ \\
\hline $204 ; 477$ & Lac grauedinem adducit \\
\hline $204 ; 480$ & Euripidis laus uini \\
\hline $204 ; 486$ & Aqua uino miscenda \\
\hline $205 ; 504$ & Lenis aquae potus \\
\hline $206 ; 510$ & 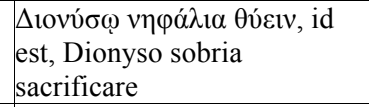 \\
\hline $206 ; 512$ & Minos \\
\hline $206 ; 516$ & Lydorum institutum \\
\hline $206 ; 525$ & $\begin{array}{l}\text { Attende adolescentulorum } \\
\text { honestum pudorem }\end{array}$ \\
\hline $206 ; 534$ & 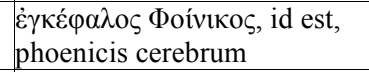 \\
\hline $206 ; 543$ & Venustum Aristonis dictum \\
\hline $207 ; 555$ & $\mu \varepsilon v o ́ \varepsilon 1 \kappa \varepsilon \varsigma$ \\
\hline $207 ; 557$ & $\begin{array}{l}\text { Studiosorum secundae } \\
\text { mensae }\end{array}$ \\
\hline $207 ; 563$ & Aristotelis opinio \\
\hline $208 ; 573$ & $\begin{array}{l}\text { Vomitus et alui subductiones } \\
\text { uitandae }\end{array}$ \\
\hline $208 ; 580$ & Peculiare uomitus malum \\
\hline $208 ; 594$ & Grana Cnidia et scamonea \\
\hline $208 ; 601$ & Optima comparatio \\
\hline $208 ; 603$ & $\begin{array}{l}\text { Leniter cientibus aluum } \\
\text { utendum }\end{array}$ \\
\hline $210 ; 643$ & Admonitio Platonis \\
\hline $210 ; 651$ & Theophrastus \\
\hline $210 ; 653$ & Animus corporis inquilinus \\
\hline $210 ; 662$ & $\begin{array}{l}\text { Versus senarius ex poeta } \\
\text { quopiam }\end{array}$ \\
\hline $210 ; 671$ & Heraclitus \\
\hline
\end{tabular}

Humanistica Lovaniensia 68.2 (2019), 257-296 


\begin{tabular}{|c|c|c|}
\hline $211 ; 680$ & & $\begin{array}{l}\text { Studiosis non uacat } \\
\text { meminisse uoluptatum }\end{array}$ \\
\hline $211 ; 684$ & & Iocus Epaminondae \\
\hline $211 ; 692$ & & Tiberius Caesar \\
\hline $211 ; 699$ & & Sui cuilibet pulsus attendendi \\
\hline $212 ; 730$ & & $\begin{array}{l}\text { Contra studiosos corpori non } \\
\text { parcentes }\end{array}$ \\
\hline $212 ; 733$ & & Festiuus apologus \\
\hline \multicolumn{3}{|c|}{$\begin{array}{l}\text { [IV.] In principe requiri doctrinam Plutarchi commentarium, Erasmo Roterodamo } \\
\text { interprete }\end{array}$} \\
\hline $217 ; 11$ & & Sententia Theopompi \\
\hline $217 ; 14$ & $\begin{array}{l}\text { Imperium non spatio, sed } \\
\text { stabilitate metiendum }\end{array}$ & $\begin{array}{l}\text { Imperium non spatio, sed } \\
\text { stabilitate metiendum }\end{array}$ \\
\hline $217 ; 20$ & & Bona similitudo \\
\hline $218 ; 31$ & & $\begin{array}{l}\text { Comparatio principis ad } \\
\text { regulam }\end{array}$ \\
\hline $218 ; 34$ & Sententia & Sententia \\
\hline $218 ; 38$ & Mos Persarum & Mos Persarum \\
\hline $218 ; 40$ & Lex omnium regina & Lex omnium regina \\
\hline $218 ; 47$ & Princeps quid sit & Princeps quid sit \\
\hline $218 ; 57$ & Iustitiae laus & Iustitiae laus \\
\hline $218 ; 61$ & Gestamen regis & Gestamen regis \\
\hline $218 ; 79$ & E poeta quopiam & E poeta quopiam \\
\hline $219 ; 79$ & Mira iustitiae vis & \\
\hline $219 ; 86$ & E poeta quopiam & E poeta quopiam \\
\hline $220 ; 88$ & Epaminondas & Epaminondas \\
\hline $220 ; 91$ & Cato Vticensis & Cato Vticensis \\
\hline $220 ; 94$ & & Clearchus \\
\hline $220 ; 95-96$ & & Aristodemus \\
\hline $220 ; 115$ & & $\begin{array}{l}\text { Attende Alexandri ad } \\
\text { Diogenem dictum }\end{array}$ \\
\hline $221 ; 131$ & Carmen & Carmen \\
\hline $221 ; 134$ & Mira similitudo & Mira similitudo \\
\hline $221 ; 139$ & Versus senarii & Versus senarii \\
\hline $222 ; 142$ & Similitudo & Similitudo \\
\hline \multicolumn{3}{|c|}{ [V.] Cum principibus maxime philosophum debere disputare } \\
\hline $225 ; 12-13$ & & Ariston Chius \\
\hline $226 ; 29$ & E poeta quopiam & E poeta quopiam \\
\hline $226 ; 31$ & 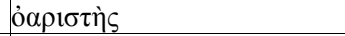 & \\
\hline $226 ; 32$ & Reges deorum discipuli & Reges deorum discipuli \\
\hline $226 ; 35$ & Mirum de capris & 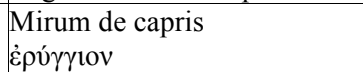 \\
\hline $226 ; 45$ & $\begin{array}{l}\text { Qui principes quos doctos } \\
\text { habuerint }\end{array}$ & $\begin{array}{l}\text { Qui principes quos doctos } \\
\text { habuerint }\end{array}$ \\
\hline $226 ; 50$ & Ironia & Ironia \\
\hline $226 ; 56$ & & 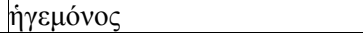 \\
\hline $227 ; 59$ & Prouerbialis senarius & Prouerbialis senarius \\
\hline $228 ; 71$ & 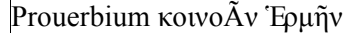 & 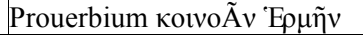 \\
\hline
\end{tabular}




\begin{tabular}{|c|c|c|}
\hline $228 ; 81$ & 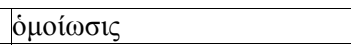 & \\
\hline $229 ; 108$ & Senarii e tragoedia quapiam & Senarii e tragoedia quapiam \\
\hline $230 ; 114$ & & Epicurus \\
\hline $230 ; 116$ & & Sententia \\
\hline $230 ; 117$ & Nomina Gratiarum & Nomina Gratiarum \\
\hline $230 ; 118$ & $\begin{array}{l}\text { Ab alacritate gaudio et } \\
\text { florulentia }\end{array}$ & $\begin{array}{l}\text { Ab alacritate gaudio et } \\
\text { florulentia }\end{array}$ \\
\hline $230 ; 124$ & O diuinitus dictum[!] & \\
\hline $230 ; 140$ & Similitudo & Similitudo \\
\hline $230 ; 146$ & Maligne de Pompeio & \\
\hline $231 ; 160$ & $\delta \varepsilon 0 \mu \varepsilon \dot{v}{ }_{0}$ & \\
\hline \multicolumn{3}{|c|}{ [VI.] Utrum graviores sint animi morbi quam corporis } \\
\hline $235 ; 17$ & & De uulpe Aesopica \\
\hline $235 ; 22$ & & Sententia aurea \\
\hline $236 ; 30$ & & Animi mala latere \\
\hline $236 ; 33$ & & $\begin{array}{l}\text { Dementia praecipuus animi } \\
\text { morbus }\end{array}$ \\
\hline $236 ; 43$ & & Prouerbium \\
\hline $236 ; 58$ & & Ex poeta quopiam \\
\hline \multicolumn{3}{|c|}{ [VII.] Num recte dictum sit $\Lambda \dot{\alpha} \theta \varepsilon$ Bı $\omega ́ \sigma \alpha \varsigma$, id est, Sic vive ut nemo te sentiat vixisse } \\
\hline $241 ; 6$ & & Sententia prouerbialis \\
\hline $241 ; 7$ & & Philoxenus \\
\hline $242 ; 26$ & & $\begin{array}{l}\text { Veteres aegrotos palam } \\
\text { curabant }\end{array}$ \\
\hline $242 ; 57$ & & Similitudo \\
\hline $243 ; 60$ & & Epaminondas \\
\hline $243 ; 63$ & & Sophoclis uersus \\
\hline $244 ; 66$ & & $\begin{array}{l}\text { Vita sedentaria marcorem } \\
\text { conciliat }\end{array}$ \\
\hline $244 ; 76$ & & Ex poeta quopiam \\
\hline $244 ; 89$ & & Sol Delius \\
\hline $244 ; 91$ & & 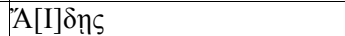 \\
\hline $244 ; 92$ & & Ex poeta quopiam \\
\hline $244 ; 93$ & & $\varphi \tilde{\omega} \zeta$ \\
\hline $246 ; 105$ & & Ex poeta quopiam \\
\hline $246 ; 120$ & & $\lambda \eta \dot{\theta} \theta \eta \ddot{\alpha} \beta v \sigma \sigma o \varsigma$ \\
\hline \multicolumn{3}{|c|}{ [VIII.] De cupiditate divitiarum } \\
\hline $252 ; 29$ & & Ex poeta quopiam \\
\hline $252 ; 66$ & & Solon \\
\hline $256 ; 169$ & & Hesiodus \\
\hline $256 ; 183$ & & $\begin{array}{l}\text { Agathon tibias ex conuiuio } \\
\text { relegauit }\end{array}$ \\
\hline $256 ; 187$ & & Versus Hesiodi \\
\hline $258 ; 206$ & & Homeri versus \\
\hline $258 ; 225$ & & Ex poeta quopiam \\
\hline
\end{tabular}




\section{0 pufcula 3 lutarcbi nup tradu}

cta. ErafmoRoterodamo Interprete.

De tuenda bona valitudine precepta,

In principe requiridoetrinam.

Cum principibus maxime philofophum debere difputare,

Vtrumgrauiores fint animi morbi g̈ corporis,

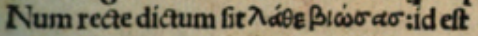

Sic viue ve nemote fentiat vixiffe,

DeCupiditate diuitiarum.

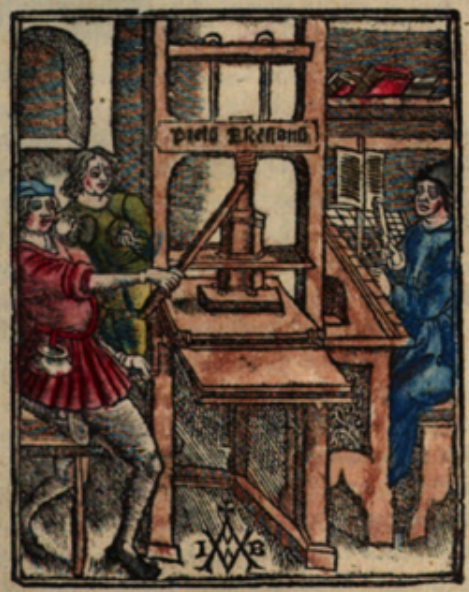

Vẹundantur vbi complura alia,\& Plutarchi \&Erafini fyntagmata, in xedibus Afcenfianis.

Plate 1: Plutarch's Moralia translated by Erasmus, printed by Badius Ascensius, presumably in 1513 or early 1514 .

Gent, Universiteitsbibliotheek, BIB.G.009091/-1, title page. 


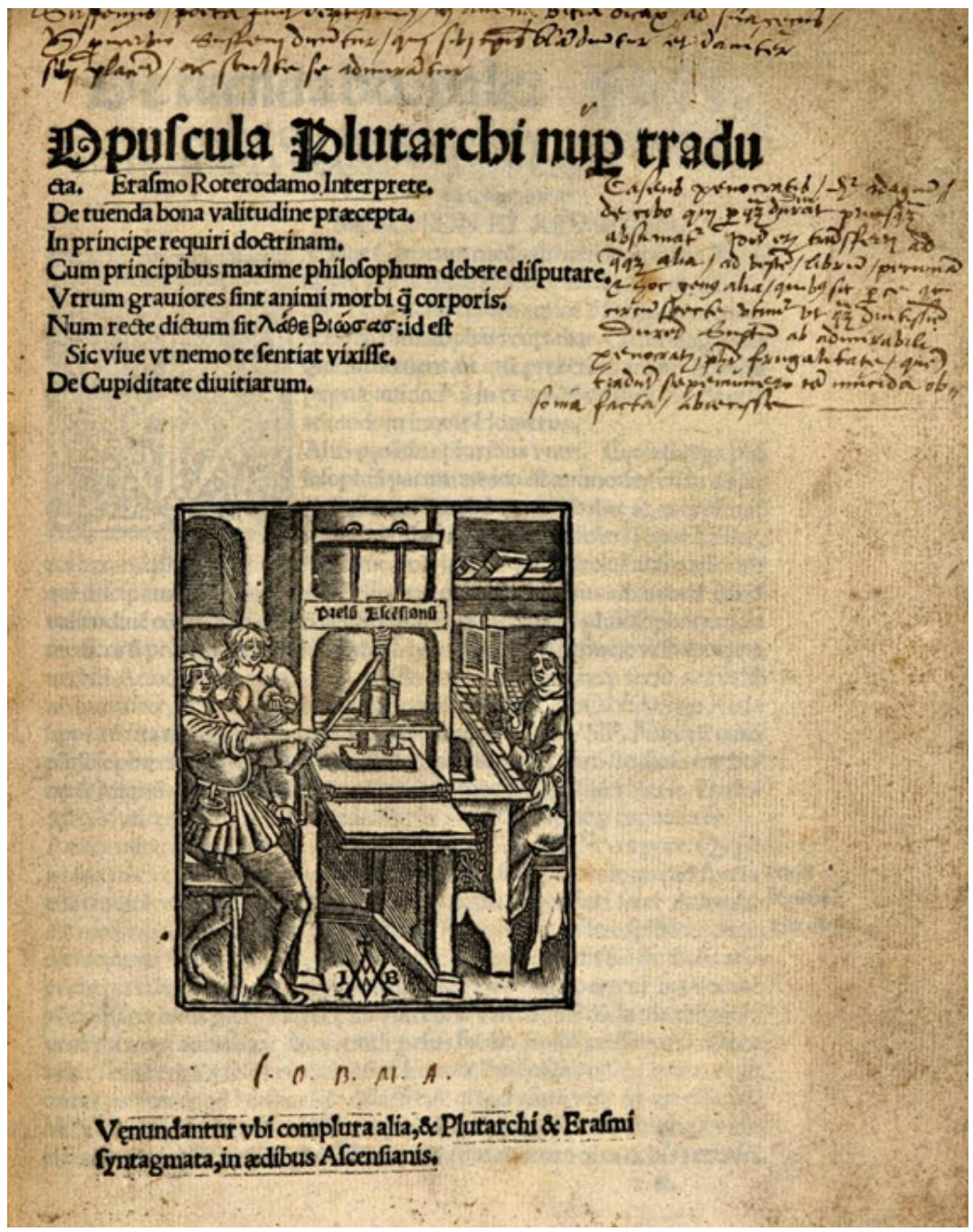

Plate 2: Plutarch's Moralia translated by Erasmus, printed by Badius Ascensius, presumably in 1513 or early 1514 .

Gent, Universiteitsbibliotheek, BIB.G.009211, title page. 


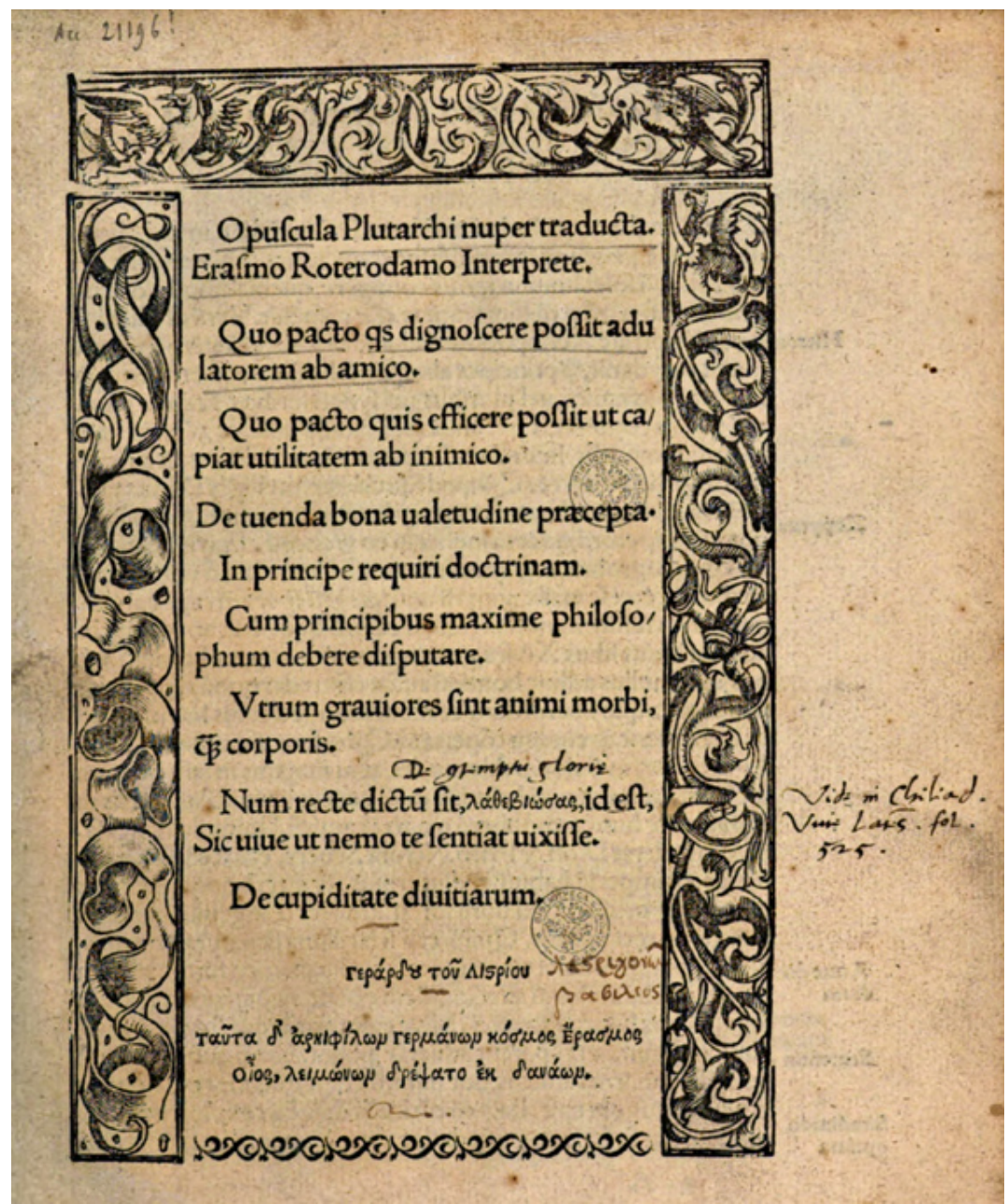

Plate 3: Plutarch's Moralia translated by Erasmus, printed by Johannes Froben in August 1514.

Gent, Universiteitsbibliotheek, BIB.ACC.021196/-1, title page. 


\section{Seccupidi.oinitianĩ. 50 :XIX.}

quicquíd luce vacat, id refugit, cog pturbat:q tenebrẹilli fufpectę terrorê icutiát. Côtra lux vfọ a deo ê iuctida, \&ramabilis:ve nihil eorti qu natura vo

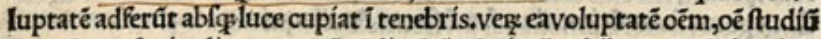

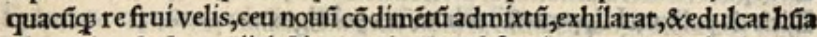
nitate.Atg hoiem cốicicit i ignorationé,\& oblcuritatê,actenebris obtegit, vitắq q̆fi fepelit, is videt hoc iṕm grauit ferre, $q$ nafcimur: \& eo reuocare

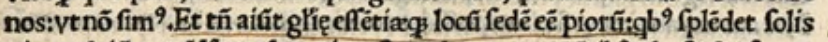
vigor:deiń noetê iferne i pratis rofeo colore purpurătib?,gbuf̨̣ itốfa ver

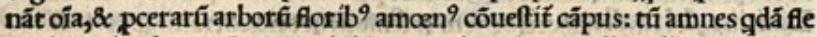
tus ígnari ac lenes efi pflufit : iṕi tráfigút iuctide tps colloquiís \& coỏméora tióe rerfi ṕteritarti ac pítíï, accerfêtes fefe mutuo \& iter fe côfuetudínévi tẹ agitătes.Porro tertia via eorf́ ê: $q$ ípie vixertit \& îiufte,aias i obfcurti lo cti \& barathrfi quoddá ṕcipítátes, vñ imêfas ructant tenebras, láguida no

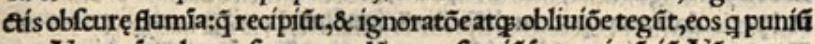
tur.Neg; eni vulturés femparrodüt epar fontifí i terra iacétíí. Ná aut exu

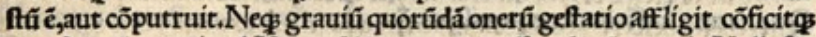
corp" eorli g puniunț. Neģ eni iã carnes aut offa cohçrêt neruis. Nullę fît corporis relige corporti vita defunetis,cruciatuti eorü capaces, $g$ fpeciê fibi

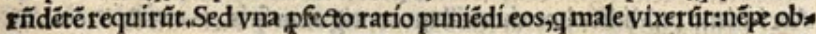

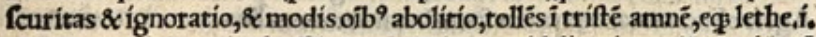
obliuione ṕcipitans in abyffiủ ac vaftai pelagus, videlicet ignauiă \& otilí:qđ̆ fuo fluctu ignorationê \& obfcuritatéfecti trahit.

Plutarchus deCupiditate Diuitiartí DESI.ERAS.Rote,interp̄te:

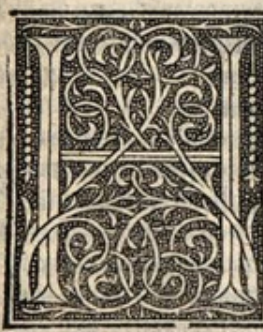
Ippomachus Aliptes/quibufdă laude efferêtibus Pręlongum quépiá ac pralongís manib? hominê Tang̈ ad pugílum certamể idoneum:fane inquít Si fufpenfa in alto corona foret detrahenda. Idem lícebít dicere in hos qui pulchra prędia,qui Amplas ędes,qui pecunię vimftupent, atg his in Rebus félicitaté fitã effe ducît: fane fi quidem. Vẹnalíseffet emenda felicitas,g̈g̈ permultos Videas/qui malint effe diuites, fimulqg míferi, Oت dato argento parare felicítatể, non emitur Nümis, anim? liber omnímoleftia, fuag cötêtus

Sorte, nec magnanímítaș,neg tranquillitas,neq

Libertas,diuitem effe non eft diuitias contemnere: Nec immodicas opes poffidere:fed non egerefuperuacaneis.

$$
\text { c iii, }
$$

Plate 4: Plutarch's Moralia translated by Erasmus, printed by Badius Ascensius, presumably in 1513 or early 1514 .

Gent, Universiteitsbibliotheek, BIB.G.009211, sig. c3r. 


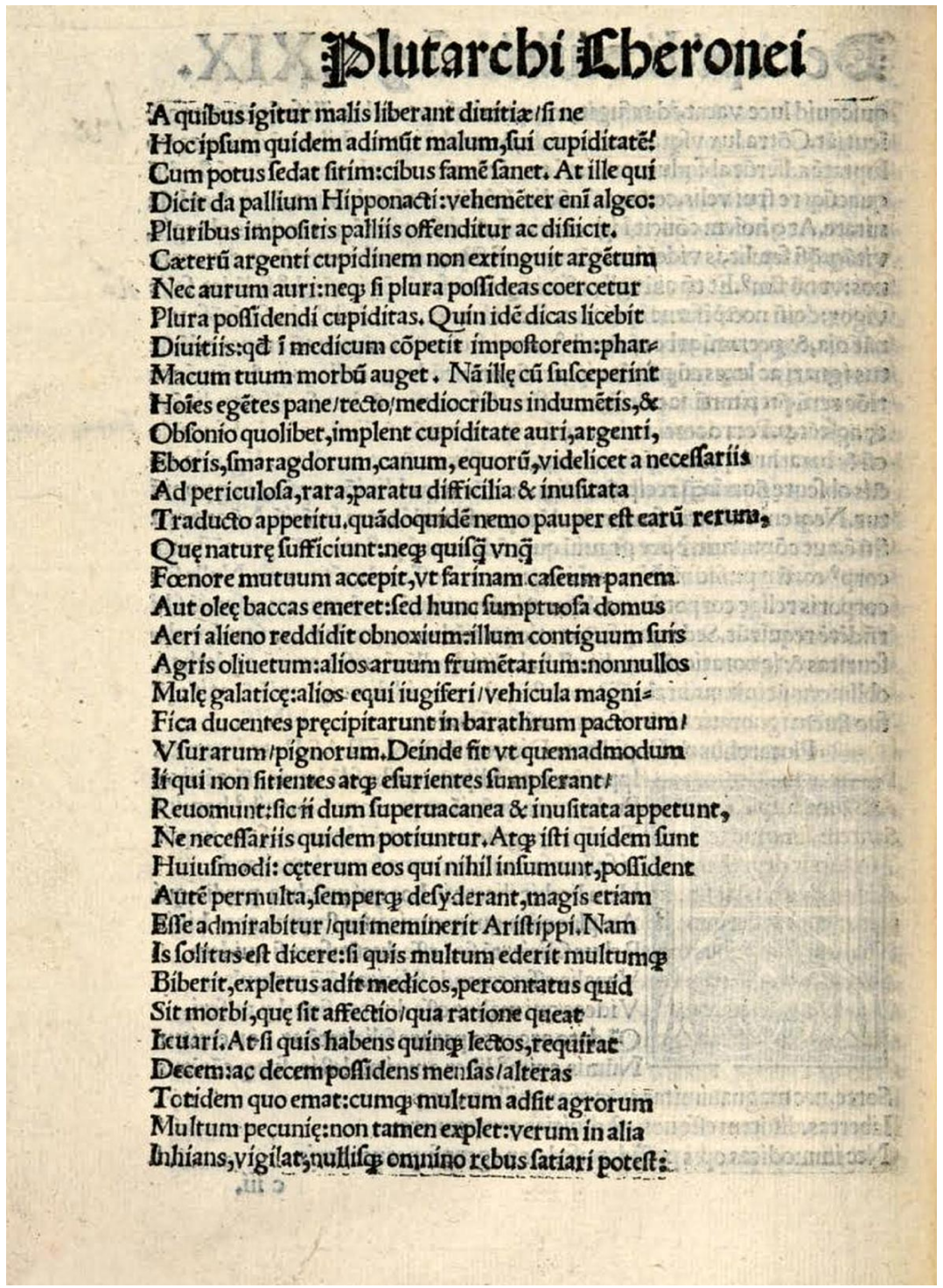

Plate 5: Plutarch's Moralia translated by Erasmus, printed by Badius Ascensius, presumably in 1513 or early 1514 .

Gent, Universiteitsbibliotheek, BIB.G.009211, sig. c3v. 


\section{PLVTAR CHI DE VTILITATE \\ Q.VOPACTO QVIS EFFICIAT VT EXINI micis capiat utilitatem, Plutarchi Chreronenfis Erafmo Roterodaumo Interprete.

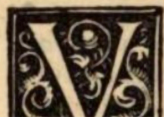 \\ Ideo quidem te Corneli pulcher placidiffimuni uit: genus, \& a reipubliczenegotips femotum,ti' bi delegiffe, in quo tamen ita maximã adfers utí \\ litarom roinublín dım nmmihurenrito adoun}

Plate 6: Plutarch's Moralia translated by Erasmus, printed by Johannes Froben in August 1514.

Gent, Universiteitsbibliotheek, BIB.ACC.021196/-1, sig. C8v.

\section{Setuendabo.pale: fo.II.}

\section{PVTARCHI DE TVENDA BONA VALETVDINE}

PRAECEPTA ERASMO INTERPRETE.

тরं $\pi \rho \dot{\sigma} \sigma \omega \pi t$

MOSCHION ET XEVSIPPVS.

V fane Glaucum medící:heri deterrebas Xeưra

Plate 7: Plutarch's Moralia translated by Erasmus, printed by Badius Ascensius, presumably in 1513 or early 1514 .

Gent, Universiteitsbibliotheek, BIB.G.009091/-1, sig. a2r.

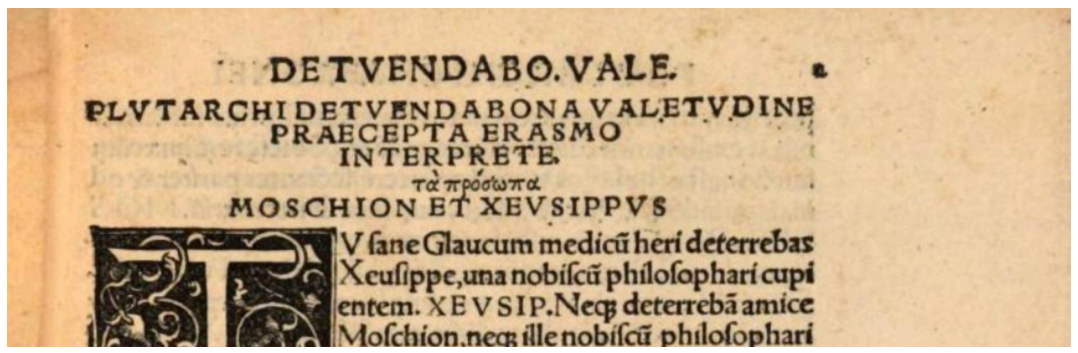

PlATE 8: Plutarch's Moralia translated by Erasmus,

printed by Johannes Froben in August 1514.

Gent, Universiteitsbibliotheek, BIB.ACC.021196/-1, sig. a2r. 


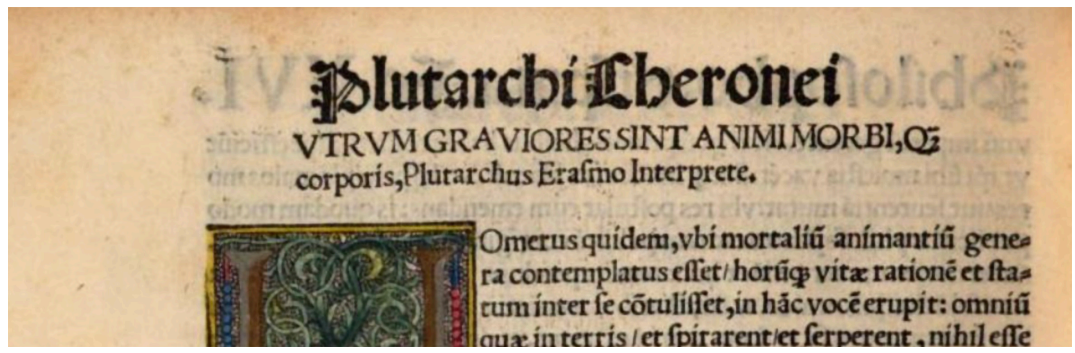

Plate 9: Plutarch's Moralia translated by Erasmus, printed by Badius Ascensius, presumably in 1513 or early 1514 .

Gent, Universiteitsbibliotheek, BIB.G.009091/-1, sig. b8v.

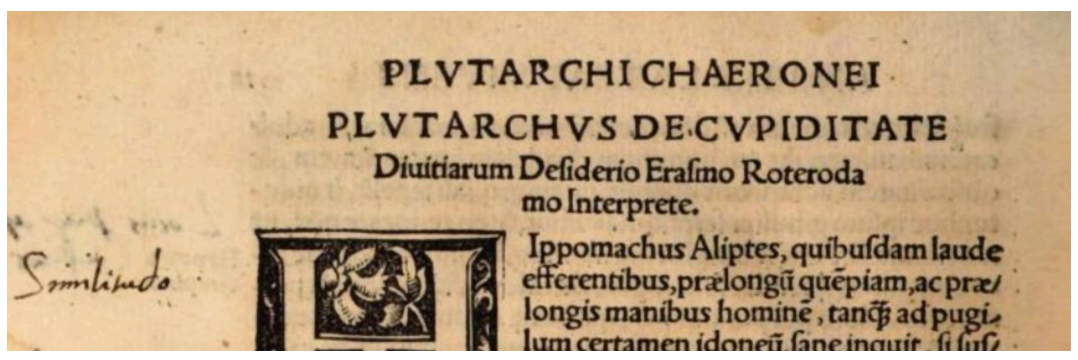

Plate 10: Plutarch's Moralia translated by Erasmus, printed by Johannes Froben in August 1514.

Gent, Universiteitsbibliotheek, BIB.ACC.021196/-1, sig. d2v. 